\title{
Revision of the plant assemblage of Steinheim am Albuch (Baden-Württemberg, Germany, middle Miocene, reference locality of Mammal Neogene Zone MN 7)
}

\author{
Johanna Kovar-Eder \& GÜnter SchweigerT
}

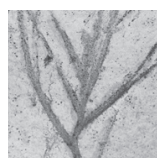

\begin{abstract}
The fossil plant assemblage of Steinheim am Albuch, reference locality of mammal Neogene zone MN 7, is revised. The plant-bearing calcareous marls (sulcatus-beds) were deposited in an impact crater lake underlying the mammalbearing strata (trochiformis- and oxystoma-beds). Currently, MN7-8 are correlated chronostratigraphically to the Serravallian and to the Sarmatian (Central Paratethys stage). The plant fossils are preserved as mere impressions, very poor in contrast. The assemblage includes aquatic plants from the lake and its margin as well as mainly leaves of woody taxa from the terrestrial surroundings. Aquatic plants include Characeae, Cladiocarya trebovensis, Phyllites sp. - ?floating leaf, Equisetum, ?Lythraceae, ?Potamogeton geniculatus, ?Trapa, and reed and sedge-like foliage ("Typha" latissima, Monocotyledoneae). In the terrestrial flora oaks are most diverse (Quercus drymeja, Q. ?gigas, Q. kubinyii, Q. mediterranea, Q. pseudocastanea). Foliage of ?Quercus sp. is more numerous than that of all other oak species but its systematic position remains unclear. Celtis japeti, C. lacunosa, Podocarpium podocarpum, Populus balsamoides, Zelkova zelkovifolia, and Sapindales leaflets of compound leaves (Sapindales fam., gen. et sp. 1 and 2) are well documented. Acer pseudomonspessulanum vel A. integrilobum, vel Acer angustilobum, ?Carpinus sp., Buxus pliocenica, Chaneya oeningensis, cf. Daphnogene polymorpha, Leguminosites cf. hesperidum, and "Parrotia" pristina are documented based on single specimens only. Not confirmed are, among others, the following taxa described by Schweigert (1993) which would be ecologically and/or climatically relevant: Isoëtes braunii recognised here as indeterminable remain, Isoëtes sp. as leaf rhachis and petiole of compound leaves, Smilax which is Celtis japeti, Pistacia miochinensis determined here as Sapindales fam., gen. et sp. 2, Zanthoxylum as ?Sapindales fam., gen. et sp. 1, "Dikotylenrest (Phyllocladium)" as fragment of a damaged leaf, and Eichhornia as indeterminable remain. The plant assemblage at Steinheim is peculiar in several respects: it lacks conifers as well as winged fruits except for Chaneya oeningensis and a poor fragment (?Ailanthus sp.). Lauraceae are practically absent except for a single specimen (cf. Daphnogene polymorpha). Betulaceae are documented by a single leaf (?Carpinus sp.) only, while taxa otherwise characteristic of this time interval like beech, elms and willows are completely absent. Assuming that the terrestrial plant record represents the close lake surroundings, the composition of taxa, leaf physiognomy and assumed autecology indicate subhumid sclerophyllous forest environment and seasonal changes in precipitation under warm-temperate climatic conditions. The Steinheim flora is compared to the regional floristic record and to selected European plant assemblages. $\bullet$ Key words: leaf flora, impact crater lake, vegetation reconstruction, middle Miocene.
\end{abstract}

Kovar-Eder, J. \& Schweigert, G. 2018. Revision of the plant assemblage of Steinheim am Albuch (BadenWürttemberg, Germany, middle Miocene, reference locality of Mammal Neogene Zone MN 7). Bulletin of Geosciences 93(4), 419-456 (9 figures, 3 tables, appendix). Czech Geological Survey, Prague. ISSN 1214-1119. Manuscript received October 17, 2017; accepted in revised form March 1, 2018; published online September 24, 2018; issued December 20, 2018.

Johanna Kovar-Eder \& Günter Schweigert, State Museum of Natural History Stuttgart, Rosenstein 1, 70191 Stuttgart, Germany; johanna.eder@smns-bw.de

The Steinheim Basin is an almost circular crater structure in the eastern part of the Swabian Alb (SW Germany), close to the town of Heidenheim an der Brenz (Fig.1). It has a diameter of $c .3 .5$ kilometres and is characterised by a remarkable uplift ("Zentralhügel") in its centre. In the surroundings of the Steinheim Basin, Upper Jurassic
(Kimmeridgian) limestones crop out, whereas in the central uplift, Middle Jurassic clays and ferruginous sandstones occur. Originally interpreted as a cryptovolcanic structure, the Steinheim Basin is today recognised as a meteoritic impact crater. This is confirmed by drillings, planar elements in quartzes from Middle Jurassic sandstones 

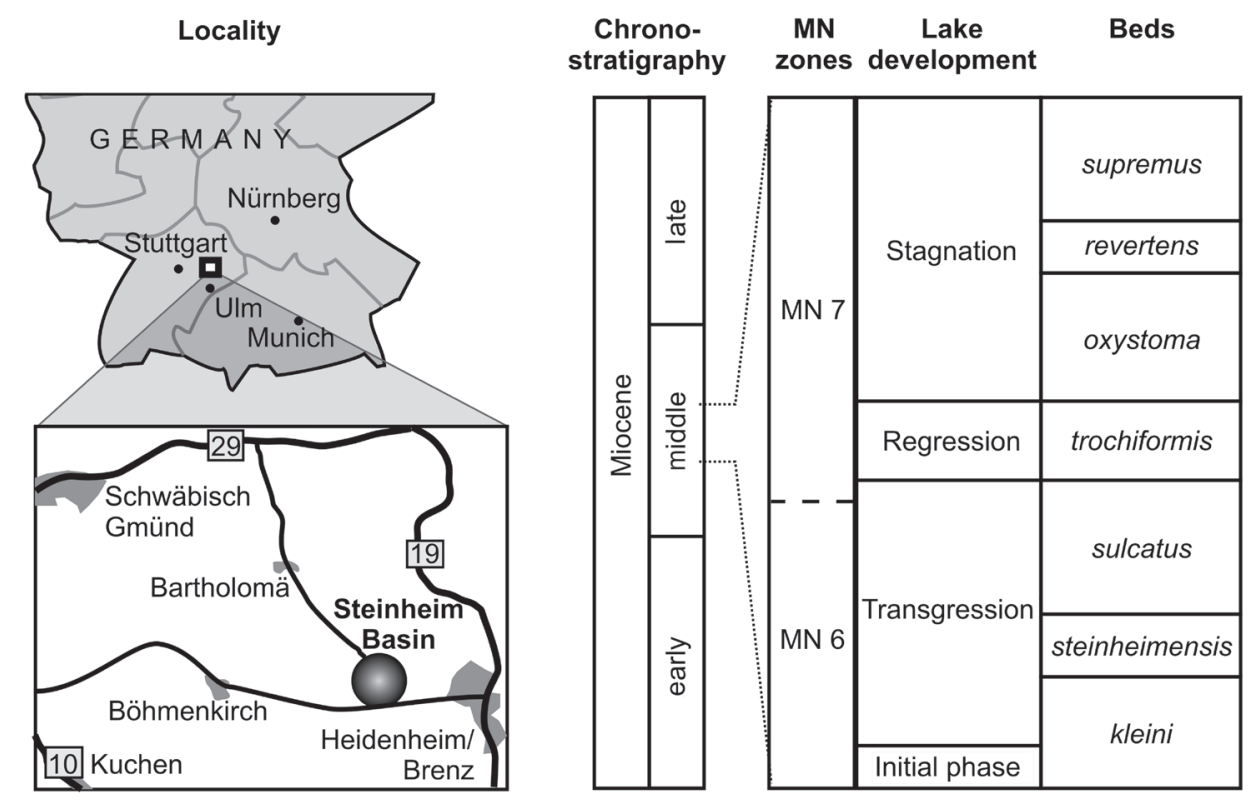

Figure 1. Location of the Steinheim Basin and its stratigraphy (from Rasser \& Covich 2014). Scale bar $=5 \mathrm{~km}$. in the central uplift area and by shatter cones diagnostic for impact structures (Buchner \& Schmieder 2017). Most recently, a fragment of the meteorite was discovered included in a shatter cone (Buchner et al. 2017) Details of the geological setting of the Steinheim Basin and a geological map of the area were provided by Reiff (2004). The geological and palaeontological research activities concerning the Steinheim Basin, dating back as far as the $17^{\text {th }}$ century, were compiled by Adam (1980).

The sedimentary filling of the Steinheim Basin consists of a basal brecciated bed followed by lacustrine deposits of the crater lake, which later developed within the basin. These lacustrine deposits are extremely rich in well-preserved fossils, especially freshwater snails. The latter comprise an endemic evolutionary lineage of the planorbid genus Gyraulus, the oldest one recorded in palaeontological science (e.g. Hilgendorf 1867; Reif 1983; Mensink 1984; Gorthner 1992; Nützel \& Bandel 1993; Povel 1993; Rasser 2006, 2013a, b). The succession of Gyraulus species provided the names for the succession of beds; from bottom to top the following beds occur (Reiff 1992): kleini-beds, steinheimensis-beds, sulcatusbeds, trochiformis-beds, oxystoma-beds, revertens-beds, supremus-beds. The lowermost available lake deposits of the Steinheim Basin, the kleini-beds, are not permanently exposed, whereas the higher beds (especially the trochiformis-and oxystoma-beds), were formerly exploited in large sand pits along the western margin of the central uplift. The underlying platy beds of the sulcatus-beds were temporarily exposed as well. They contain abundantly articulated fish remains and the herein described plants. The bulk of the lake deposits exposed at the hillside of the central uplift consist of poorly consolidated material, which is, however, locally better cemented and formed a girdle of firm carbonate rocks along the top margins of the central uplift (Wolff \& Füchtbauer 1976). Today these limestones, which interfinger with the low-cemented sands, occur only as relics due to former quarrying. Both geochemical studies and isotopic data suggest that the isolated Steinheim freshwater lake became alkaline under the prevailing climatic and environmental conditions (Bajor 1965, Tütken et al. 2006).

Besides numerous autochthonous ostracod taxa (Janz 1992, 1997) and two taxa of fish (Gaudant 1989), a very rich allochthonous terrestrial fauna was washed into the lake, e.g. land snails (Finger 1998, Höltke \& Rasser 2015, and references therein) along with a diverse vertebrate fauna (e.g. Heizmann 1992, Heizmann \& Hesse 1995, Heizmann et al. 1996). The rich mammalian fauna recovered from the Steinheim Basin was used to define the Neogene Mammal Unit MN7 (Mein 1975, 1989; Heizmann 1992; Steininger 1999). It includes Insectivora (Mioechinus intermedius, Galerix socialis, Heterosoricinae, Soricinae, Dinosorex sansaniensis), Chiroptera (Vespertilionidae, Eptesicus campanensis), Lagomorpha (Prolagus oeningensis, Lagopsis verus, Eurolagus fontannesi), Rodentia (Spermophilinus bredai, Microdyromys complicatus miocaenicus, Miodyromys aegercii, Myoglis meini, Megacricetodon minor, Megacricetodon germanicus, Democricetodon mutilus, Democricetodon gaillardi, Eumyarion cf. latior, Anomalomys gaudryi, Steneofiber depereti, Trogontherium minutum), Carnivora (Paralutra jaegeri, lschyrictis mustelinus, Martes cf. filholi, Proputorius sp., Trochotherium cyamoides, Trocharion albanense, Amphicyon steinheimensis, Amphicyonopsis? serus, 
Hemicyon goeriachensis, Ursavus cf. intermedius, Pseudaelurus quadridentatus, Pseudaelurus lorteti, Sansanosmilus jourdani, Semigenetta sansaniensis), Perissodactyla (Anchitherium aurelianense, Alicornops simorrense, Lartetotherium sansaniense, Dicerorhinus steinheimensis, Metaschizotherium fraasi), Proboscidea (Gomphotherium steinheimense), and Artiodactyla (Listriodon splendens, Conohyus simorrensis, Albanohyus pygmaeus, Micromeryx flourensianus, Euprox furcatus, Heteroprox larteti, Palaeomeryx eminens, Dorcatherium crassum) (Mein 1989, modified after Heizmann in Heizmann \& Reiff 2002). Most recently, an additional moschid species, ?Micromeryx eiselei, was recognised within the Steinheim fauna (Aiglstorfer et al. 2017).

The Steinheim Basin is usually interpreted as being coeval with the formation of the nearby Ries Impact Crater (Reiff 1988, 1992; Heizmann \& Reiff 2002) although direct proof is lacking. The Ries impact was dated by various radiometric methods at $\sim 14.9 \mathrm{Ma}$ (Buchner et al. 2013).

The fossil plant assemblage of Steinheim is of major interest: It derives from the lake-filling of this meteoritic impact crater where surface influx by streams has not been recorded; thus, the flora probably stems from the immediate surroundings of the lake. The mammal fauna from the superimposed trochiformis- and oxystoma-beds serves as a reference for Neogene Mammal Unit MN 7. Plant assemblages dated to this time interval by means other than plant remains (independent dating) are rather rare in the European record. The flora from Steinheim has been treated taxonomically by Gregor (1983) and later by Schweigert (1993), both with rather scanty descriptions. The plant remains are poorly preserved and diagnostically relevant features are difficult, if at all, to discern. This very poor preservational state hampers the systematic treatment. Nonetheless, this revision is essential for several reasons: (1) to provide proper descriptions of the reported taxa as a sound basis for the ecological interpretation; (2) to contribute to our knowledge about the development of the flora and vegetation in Europe during the Miocene; (3) this plant taphocoenosis provides essential complementary information on the unique ecosystem of the Steinheim impact crater lake; (4) it complements the record from Randeck Maar (Mammal Neogene Unit MN 5).

\section{Material and methods}

The large collection of plant material from Steinheim at the State Museum of Natural History Stuttgart, which comprises more than 400 specimens, was reinvestigated including also a few specimens from the Meteorkratermuseum Steinheim. This material was the main source for previous studies by Gregor (1983) and Schweigert (1993). The poorly preserved plant material impressions in calcareous marls - is very poor in contrast. Often, the leaf margin and even the secondary venation are hardly traceable, accounting for several taxa whose systematic position is questionable. Descriptions largely follow Ellis et al. (2009). Most material was already inventoried prior to this investigation. However, specimens numbered P2227 have been inventoried in the course of this study. Material numbered P2231 has been collected most recently. For description of calcified remains of Characeae, Cladiocarya trebovensis (Bůžek) Mai and Celtis lacunosa (Reuss) Kirchheimer we refer to Gregor (1983).

In the description section, information on secondary vein spacing refers to the central part of the lamina; measurement values in brackets represent the estimated full length or width after reconstruction of a leaf fragment. Abbreviations: 1 - length; w - width; SMNS State Museum of Natural History Stuttgart; MKM Meteorkratermuseum Steinheim. All inventory numbers of SMNS start with "P".

\section{Systematic Palaeontology}

The systematics of angiosperms follows Heywood et al. (2007).

Algae

Characeae

"Chara zolleriana Heer" vel "Characeenstengel"

Remarks. - See Gregor (1983, pl. 4, figs 3-5).

\section{Chara sp.}

Remarks. - See Gregor (1983, pl. 4, figs 1, 2).

Equisetaceae

Equisetum sp.

Figure 2A, B, E

1993 Phragmites oeningensis A. Braun. - Schweigert, p. 81, partim.

Material. - P1674/2, 5-8, 12.

Description. - Articulate shoot fragments, vascular strands alternating at nodia; specimen P1674/7: axis with telescope-like apex, specimen P1674/8 with several articulate shoots arising at a single base. 
Remarks. - Specimens P1674/1-22, all assigned to Phragmites oeningensis (Schweigert 1993), partly unambiguously represent Equisetum sp. due to the articulate and telescope-like organisation and the alternating position of the vascular bundles at the nodia. The latter feature is visible weakly on the specimens at hand.

Angiosperms

Laurales

Lauraceae

\section{Daphnogene cf. polymorpha (A. Braun) Ettingsh.}

Figure $3 \mathrm{~N}$

1983 Dicotylophyllum sp. (Sapotaceae). - Gregor, p. 17, pl. 2 , fig. 1.

1993 Daphnogene polymorpha (A. Braun) Ettingshausen 1851. - Schweigert, p. 64, sine fig.

Material. - P1243/5.

Description. - Elliptic, probably coriaceous leaf, petiole not preserved, $1 \times \mathrm{w}=38(? 40) \times 20 \mathrm{~mm}$, ratio $1 / \mathrm{w}$ about 2 , base shape probably straight, base angle acute, apex ?complete, shape convex, ?blunt, margin entire; midvein straight, basal secondaries faintly visible, suprabasal acrodromous.

Remarks. - The suprabasal lowermost secondaries along with the probably firm texture and the entire margin account for the assignment. In the figure captions, Gregor (1983) listed this specimen as Dicotyophyllum sp. (aff. Rhodomyrtophyllum). The fossil-genus Rhodomyrtophyllum (Myrtaceae) is, however, restricted to the Eocene.

Monocotyledons

?Potamogetonaceae

\section{?Potamogeton geniculatus A. Braun in Heer}

Figure 2I

1993 Potamogeton geniculatus A. Braun in Heer. Schweigert, p. 80, pl. 5, fig. 4.

Material. - P1675/1 (Schweigert 1993, pl. 5 fig. 4), 3, 5-11, 13, 14, 16-26, 31, 32.

Description. - Multiply-branched fragments of herbaceous plants; axis slender, zig-zag course induced by forking or leaf insertion respectively, about $1 \mathrm{~mm}$ wide, lineal foliage adherent, leaves up to $45 \mathrm{~mm}$ long, up to $1 \mathrm{~mm}$ wide near the base, tapering along length into a linear acute apex, occasionally a central vein visible which is stronger than further parallel-running veins.

Remarks. - These remains very likely represent vegetative structures of an aquatic plant. Although in the fossil record Potamogeton fruits are by far more common than vegetative remains, not a single fructification is available at Steinheim. This fact and the scarcity of morphological features of these remains account for the uncertainty of the generic assignment.

\section{Cyperaceae}

\section{Cladiocarya trebovensis (Bůžek) Mai}

Remarks. - See Gregor (1983, pl. 4, figs 6, 7).

?Typhaceae

\section{"Typha" latissima A. Braun}

Figure 2F, G

1851 Typha latissima; A. Braun in E. Stitzenberger, p. 75.

1993 Phragmites oeningensis A. Braun. - Schweigert, p. 81, partim.

Material. - P1674/1.

Description. - Linear leaf fragment, $490 \mathrm{~mm}$ long (incomplete) and $20 \mathrm{~mm}$ wide with densely spaced venation, paralleling the length axis; less strong veins are intercalated between stronger ones; occasional faint transversal veins present.

Remarks. - The transversal veins account for the assignment to this taxon.

\section{Monocotyledoneae gen. et sp. indet.}

Figure 2C, D, H

1993 Isoëtes braunii (Unger) Heer 1855. - Schweigert, p. 64.

1993 Phragmites oeningensis A. Braun. - Schweigert, p. 81, partim.

Material. - P1674/20, P2215, P2227/8, numerous specimens sine no.

Figure 2. A, B, E - Equisetum sp.; A, B - P1674/7; E - P1674/8. • C, D, H - Monocotyledoneae gen. et sp. indet.; C, D - P2215; H - P2227/8. • F, G - "Typha" latissima A. Braun, P1674/1. • I - ?Potamogeton geniculatus A. Braun in Heer, P1675/1. Scale bar $=10 \mathrm{~mm}$. 


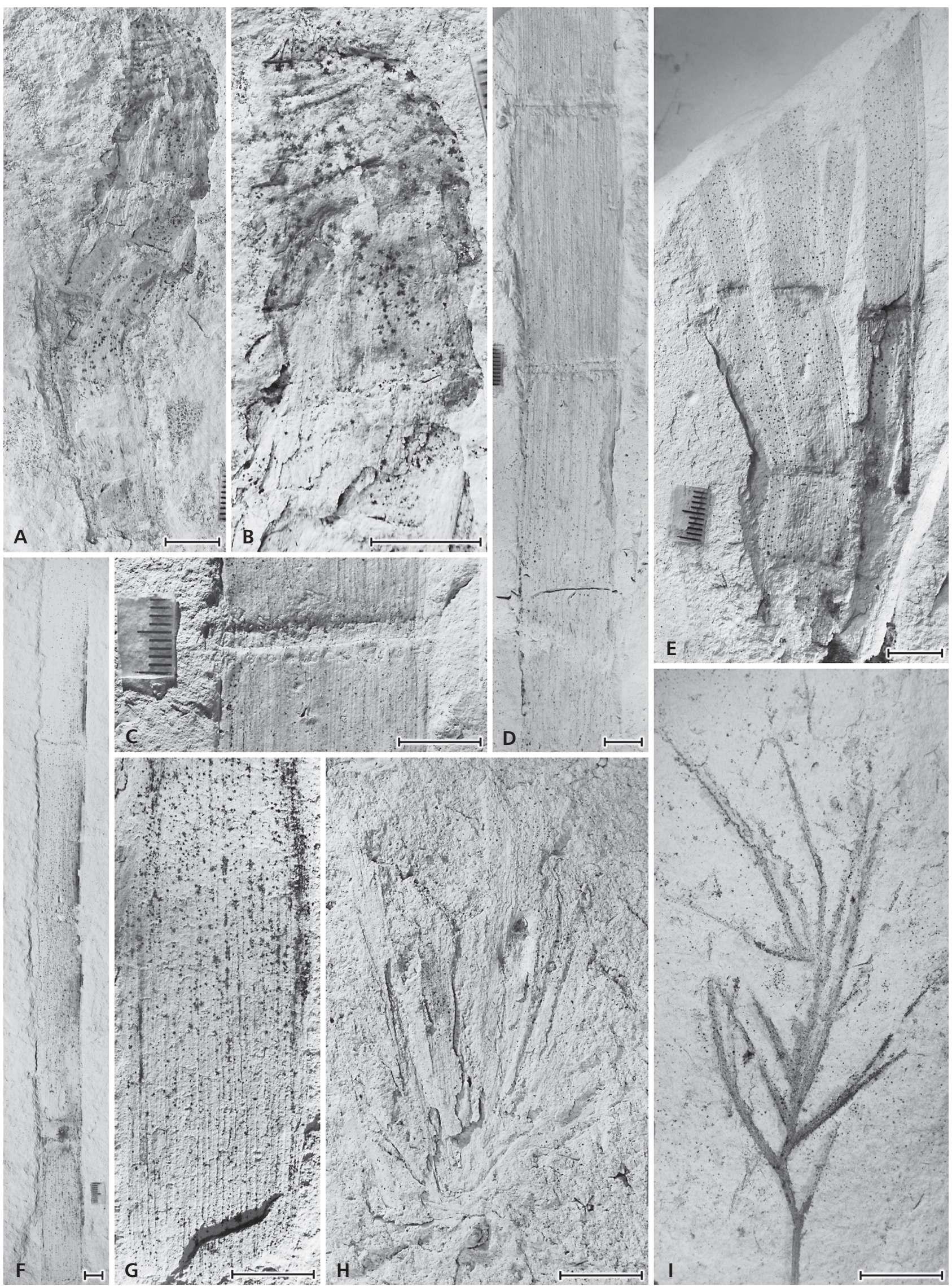


Description. - Fragments of lineal, parallel-veined foliage and a basal cluster of narrow, lineal foliage (P2227/8).

Remarks. - Critically, these specimens cannot be assigned even to the family level. Schweigert (1993) described Isoëtes braunii as a whole plant consisting of a cluster of very narrow leaves and a very short axis numbered P1670/1, but left this specimen unfigured. In the SMNS collection, specimen $\mathrm{P} 1670 / 1$ is a problematic remain, probably a leaf petiole but definitely not the specimen described by Schweigert as Isoëtes braunii. The specimen Schweigert (1993) had at hand is on display in MKM. It is an indeterminable remain.

Eudicots

Buxaceae

\section{Buxus pliocenica Saporta \& Marion}

Figure 30

1876 Buxus pliocenica Sap. et Mar.; Saporta \& Marion, p. 144 , pl. 32, figs 6-8.

1993 Buxus cf. pliocenica Saporta et Marion 1876. Schweigert, p. 74, partim, non pl. 1, fig. 4.

Material. - P1650/2.

Description. - Elliptic, entire-margined leaf, $1 \times \mathrm{w}=$ $28(30) \times 15 \mathrm{~mm}$, ratio $1 / \mathrm{w}$ about 2 , petiole lacking, base shape straight to somewhat convex, base angle acute, apex shape convex, uppermost part not preserved, midvein stout, straight, secondaries very densely spaced, originating at angles of $40-45^{\circ}$.

Remarks. - Under strongly oblique light the densely spaced secondary veins characteristic of Buxus are visible. In contrast, specimen P1650/1, which was figured by Schweigert (1993, pl. 1, fig. 4), cannot be assigned to Buxus due to the lack of diagnostically relevant characters.

Saxifragales

Hamamelidaceae

\section{"Parrotia" pristina (Ettingsh.) Stur}

Figure 5I

1851 Styrax pristinum Ettingsh.; Ettingshausen, p. 19, pl. 3 fig. 9.
1867 Parrotia pristina Ett. - Stur, p. 192, pl. 5, figs $2,3$.

1993 Parrotia pristina (Ettingshausen) Stur 1867. Schweigert, p. 65 , pl. 2, fig. 3.

Material. - P1649/1 (Schweigert 1993, pl. 2, fig. 3).

Description. - Fragment of an elliptic to slightly obovate leaf, petiole bent, $6 \mathrm{~mm}$ long, $1 \times \mathrm{w}=60 \times 30 \mathrm{~mm}$, ratio $1 / \mathrm{w}=2$, base shape rounded, base angle obtuse, apex shape convex, apex angle obtuse, margin entire to apically ?distantly crenate, midvein slender, rather straight, secondaries ascending steeply, the first pair arising directly and opposite at the base, secondaries rather parallel among each other, widely spaced, in the middle part of the lamina up to $20 \mathrm{~mm}$, tertiaries percurrent.

Remarks. - The generic affinity of such leaves is ambiguous because, among Hamamelidaceae, leaves of Fothergilla and Hamamelis resemble that of Parrotia.

Myrtales

?Lythraceae

?Trapa sp.

Figure 9G

Material. - P2227/1.

Description. - Fragment $26 \mathrm{~mm}$ long, 5-6 mm wide, widened $(8-? 9 \mathrm{~mm})$ and rim-like thickened at the top, surface with several rugulae paralleling the length axis; at the top, somewhat offset, densely spaced bristles, about $3 \mathrm{~mm}$ long.

Remarks. - The true outlines of this remain are unclear. The top (?apex) is reminiscent of the neck and corolla of a rather large-sized Trapa fruit.

?Lythraceae gen. et sp.

Figure 9A, B

1993 "Sapindus" falcifolius A. Braun 1845. - Schweigert, p. 73 , non pl. 1, fig. 3 .

Material. - P1667/25.

Description. - Short-petiolate, ?coriaceous, entire-mar-

Figure 3. A, B, D-F - Quercus drymeja Unger; A - P1667/8; B - P2227/12; D - P1655/13; E - P1664/47; F - P1664/26. • C, G - ?Quercus drymeja Unger; C - P1664/33; G - P1664/52. • H-L - Quercus mediterranea Unger; H - P1678/12; I - P1243/11; J - P1666/2; K - P1678/1; L- P2227/9. • M - Quercus ?gigas Göppert emend. Walther \& Zastawniak, P1666/3. • N - cf. Daphnogene polymorpha (A.Braun) Ettingsh., P1243/5. • O - Buxus pliocenica Saporta \& Marion, P 1650/2. • P, Q - Quercus kubinyii (Kováts ex Ettingsh.) Czeczott; P - P1243/3; Q - P1666/1. • R - Chaneya oeningensis (Heer) Teodoridis \& Z. Kvaček, P1657/1. Scale bar $=10 \mathrm{~mm}$. 


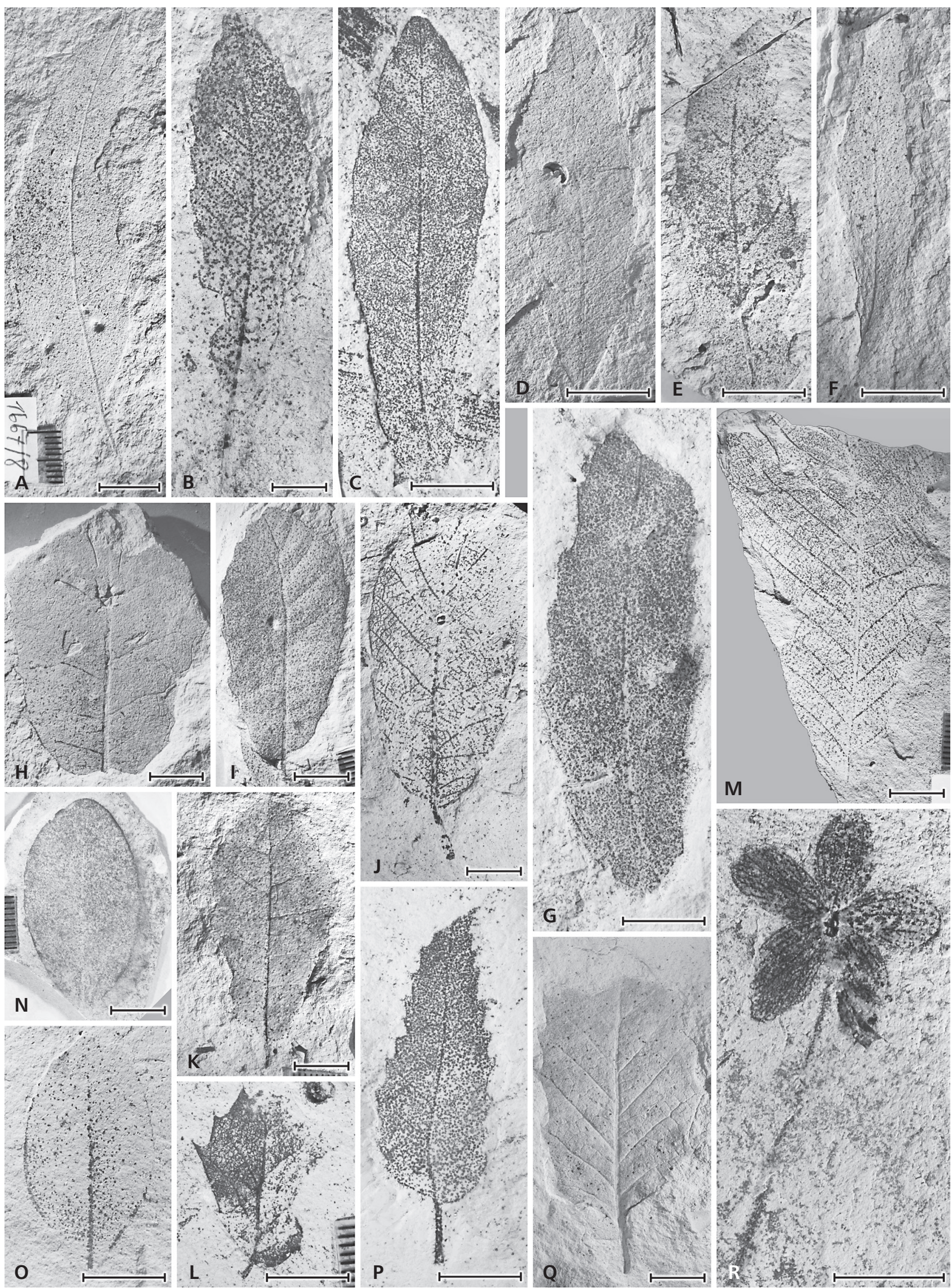


gined leaf, petiole $2 \mathrm{~mm}$ long (?complete), laminar shape slender oblong, $1 \times \mathrm{w}=50 \times 10 \mathrm{~mm}$, ratio $1 / \mathrm{w}=5$, base shape asymmetric, convex, angle acute, apex attenuate; midvein straight, secondary veins very densely spaced, ascending steeply, originating at an angle of about $40^{\circ}$, weakly brochidodromous, forming a composed intramarginal vein, intersecondaries dense, secondaries only slightly stronger than other veins, all forming a very dense network of elongated meshes.

Remarks. - The dense venation and the intramarginal vein may indicate Lythraceae affinity. The rather steeply ascending secondaries, the base shape, and the relatively small size of this leaf distinguish it from Decodon gibbosus (Kvaček \& Sakala 1999), Decodon sp. (Kovar-Eder et al. 2002) and Apocynophyllum neriifolium (cf. Lythraceae) (Kunzmann \& Walther 2007). Lythraceae from Randeck Maar (Rasser et al. 2013) differ by less dense secondary venation. Although the occurrence of Lythraceae foliage would be reasonable in the Steinheim assemblage, another affinity cannot be ruled out. Similar venation patterns occur, e.g. among Moraceae, Apocynaceae, and Myrtaceae (Kvaček \& Sakala 1999).

Fabaceae

\section{Leguminosites cf. hesperidum (Unger) Kovar-Eder \& Kvaček}

Figure 8A

1993 Leguminocarpon sp. - Schweigert, p. 72, pl. 4, fig. 3.

Material. - P1661/1 (Schweigert 1993, pl. 4, fig. 3).

Description. - Elongated, slightly S-shaped, pluriloculate pod, acute at base and apex, $85 \mathrm{~mm}$ long, maximum width $15 \mathrm{~mm}$, base and apex acute, irregularly contracted, venation weakly preserved, probably transversal, placentation marginal, one almost mature seed in the centre, diameter $9 \times 15 \mathrm{~mm}$; additionally ?abortive seeds one near the base and two towards the apex.

Remarks. - This pod differs by size and number of seeds from those of Podocarpium podocarpum (A. Braun) Herendeen which is also represented in Steinheim (see below). It resembles Leguminosites hesperidum, but more material would be desirable to confirm this assignment.
L. hesperidum is a fructification type that occurs abundantly in some time intervals such as the middle Miocene, e.g. Öhningen (Heer 1859), Hungary (Hably 1992), Parschlug (Kovar-Eder et al. 2004).

\section{Podocarpium podocarpum (A. Braun) Herendeen}

Figure 8B-F, I

1845 Gleditsia podocarpa. - A. Braun, p. 173.

1983 Gleditsia knorrii (Heer) Gregor. - Gregor, p. 15, pl. 3, figs 2-4.

1983 Gleditsia lyelliana (Heer) Hantke. - Gregor, p. 15, pl. 3, fig. 1.

1992a Podocarpium podocarpum (A.Braun) Herendeen comb. nov. - Herendeen, p. 41.

1993 Gleditsia knorrii (Heer) Gregor et Hantke 1980 sensu novo. - Schweigert, p. 71, pl. 4, figs 1, 2.

Material. - Leaflets: P1660/1 (Schweigert 1993, pl. 4, fig. 2), 2-5, 9, 11-16, 18, 20, 22-27, 29-42, 45, 46, 48-50, 56-62, 65-69, 73, 74, 77, 78, 80-97, 101, 102, 104-106, $108,109$.

Fragments of compound leaves: P1660/47, 98, 107, 113, 116, 117.

Pods and seeds: P1243/8-10 (Gregor 1983, pl. 3, figs 2-4), 9, P1659/1 (Schweigert 1993, pl. 4, fig. 1), 2-15, 17, 18, 22, 23, 25-30, 32, 33, 35-37, 39; P2227/2, 3.

To be excluded due to poor preservation or problematic identification: P1659/16, 20, 21, 24,31; P1660/7, 8, 10, 17, 19, 21, 28, 38, 43, 44, 70-72, 75, 76, $79,99,100,103,110-112$.

Description. - For description we refer to Rüffle (1963, p. 205) and restrict it to P1660/113 and 116, fragments of compound leaves: fragments of compound, paripinnate (P1660/113) leaves with up to at least 5 pairs (fragments) of opposite leaflets; leaflets slender oblong, parallelsided, $1 \times \mathrm{w}=$ up to $30 \times 10 \mathrm{~mm}$, ratio $1 / \mathrm{w}=3$, sessile, entire-margined, base strongly asymmetrical, base shape convex, base angle acute to obtuse, apex slightly emarginate; secondaries delicate, only faintly discernable; in P1660/113 lower leaflet to the right with prolonged basal secondary vein.

Remarks. - This is one of the most common fossil species at Steinheim and, except for Celtis, it is the sole one of which both leaves and fructfications (pods and seeds) are doubtlessly available. Besides numerous isolated

Figure 4. A-M - ?Quercus sp.; A - P1664/31; B - P1664/38; C, D - P1243/1 part and counterpart; E - P1664/11; F - P1664/48; G - P1664/1; H - P1243/2; I - P1664/57; J - P1664/25; K - P1664/39; L - P1664/51; M - P1664/15. • N - Myrica sp., P1668/3. • O - ?Myrica sp., P1668/6. P - cf. Quercus pseudocastanea Göppert, P1663/3. Q Q, R - Quercus pseudocastanea Göppert; Q - P1663/2; R - P1663/1. Scale bar $=10 \mathrm{~mm}$. 


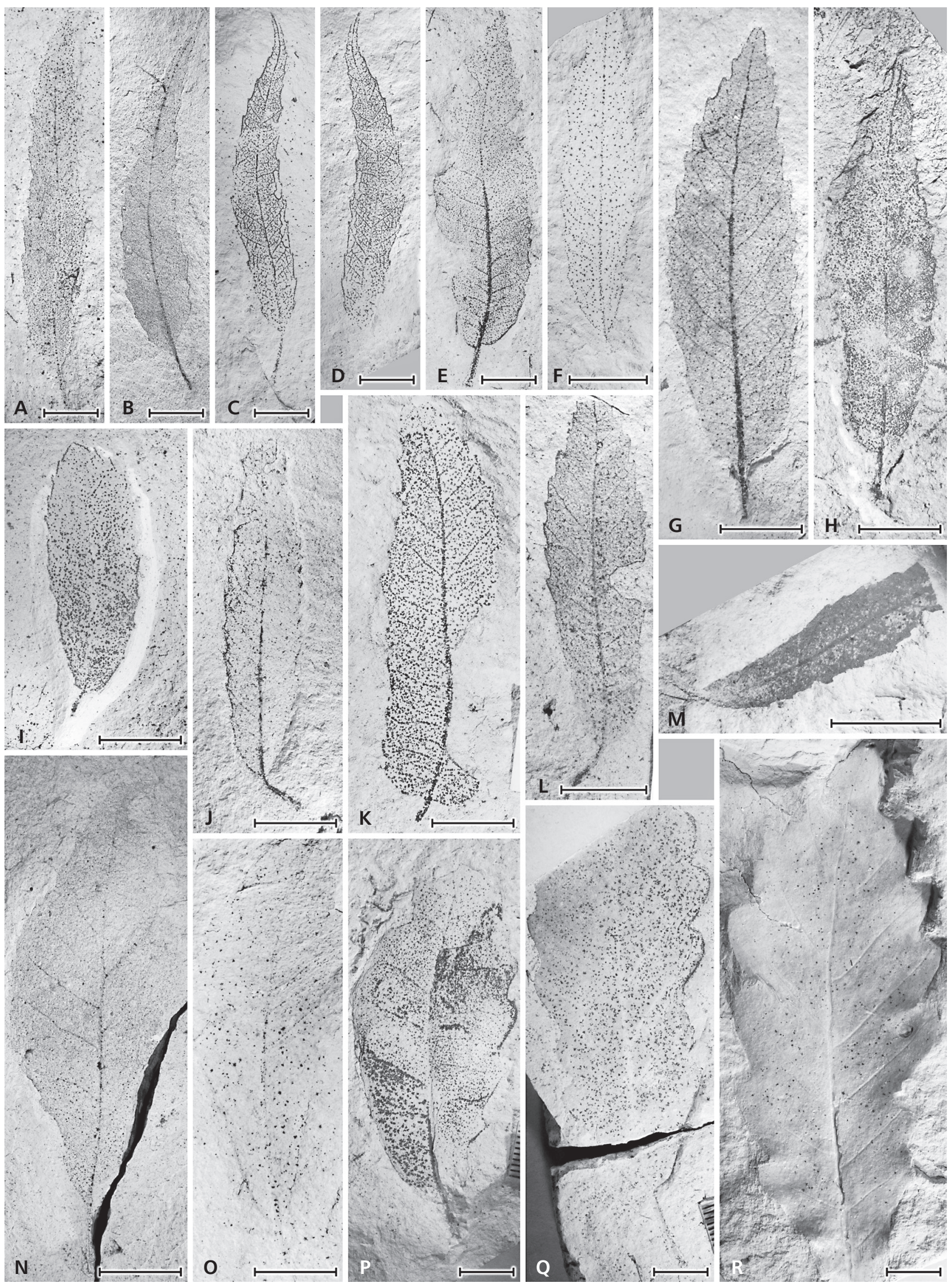


leaflets, even some fragments of compound leaves are available. Few fossil species are as well understood as $P$. podocarpium and there are no doubts that this foliage and pods derive from a single plant species (Herendeen 1992a, b). In Figure 8D, E the diagnostically valuable venation details are well visible.

Fagales

Betulaceae

\section{?Carpinus sp.}

Figure 5J

1993 Alnus gaudinii (Heer) Knobloch \& Kvaček. Schweigert, p. 65 , pl. 5 , fig. 1.

Material. - P1676/1 (Schweigert 1993, pl. 5, fig. 1).

Description. - Petiolate leaf, petiole straight, $9 \mathrm{~mm}$ long, about $1 \mathrm{~mm}$ wide, basally slightly swollen, laminar shape elliptic, $1 \times \mathrm{w}=40(? 45) \times 18 \mathrm{~mm}$, ratio $1 / \mathrm{w}$ about 2.5 ; base shape straight to slightly convex, base angle acute, apex?, margin minutely probably double serrate but teeth indistinct; midvein straight, slender, secondaries delicate, almost straight, dehiscence angle $30-45^{\circ}$.

Remarks. - This single remain may point to the presence of Carpinus rather than Alnus in the Steinheim assemblage. The serration details and the terminal course of the secondaries near the leaf margin are obscure, and the tertiaries are not preserved, accounting for the ambiguous assignment.

Fagaceae

\section{Quercus drymeja Unger}

Figure $3 \mathrm{~A}-\mathrm{G}$

1847 Quercus drymeja; Unger, p. 113, pl. 32, figs 1, 2, 4, (non 3).

1993 Quercus drymeja Unger 1847. - Schweigert, p. 66, partim, non pl. 2, fig. 5 .

1993 Zelkova zelkovaefolia (Unger) Bůžek et Kotlaba in Kotlaba 1963. - Schweigert, p. 69, partim, (P1655/13), non pl. 3, fig. 1.

1993 "Sapindus" falcifolius A. Braun 1845. - Schweigert, p. 73, partim, (P1667/8).
2004 Quercus drymeja Unger. - Kovar-Eder et al., p. 61, pl. 4, figs $1-7$.

Material. - P1655/13, P1664/?16, 22, 26, ?33, 47, ?52, P1667/8, P2227/?11, 12.

Description. - Long-petiolate leaves, petiole up to $16 \mathrm{~mm}$ long (P2227/12), laminar shape slender, elliptic to oblong to slightly ovate or obovate, $1 \times \mathrm{w}=40(? 42)-67(? 70) \times$ 9-20 mm, ratio $1 / \mathrm{w}$ between (?3.1) 3.5-4.7; base shape cuneate to somewhat convex, base angle acute, apex shape acuminate, attenuate, apex angle (narrow) acute; margin simple serrate starting not directly at the base but in the upper part of the lower third of the lamina, teeth regularly spaced, 4-6 $\mathrm{mm}$, shape variable, acute, spiny to a bit hook-shaped, usually one above a secondary vein, basal side long, straight to convex, apical side very short, straight to concave, sinus rounded, apex acute; midvein straight to sightly bent, secondaries mainly straight, simple craspedodromous, ending in the teeth, secondary spacing $4-6 \mathrm{~mm}$ in the central part of the lamina, angle of origin $45-50^{\circ}$, tertiaries probably percurrent (P2227/12).

Remarks. - These specimens were assigned by Schweigert (1993) to different taxa (see synonymy). Based on the handwritten label, specimen P1664/47 (Fig. 3E) firstly was assigned to aff. Fagus attenuata by Gregor, whereas Schweigert (1993) included it in his group of $Q$. drymeja which partly conforms to ?Quercus sp. in this paper. This specimen differs, however, from the latter group by its larger size, less dense secondaries and the shape of the teeth. Although the shape of specimen P1667/8 (Fig. 3A) is somewhat asymmetrical, the spiny marginal teeth do not point to "Sapindus" falcifolius as Schweigert (1993) supposed. For specimen P1664/52 (Fig. 3G) the assignment to $Q$. kubinyii cannot be excluded. If details of the secondary and tertiary venation and serration are unclear, it may be difficult do differentiate $Q$. drymeja from Myrica, e.g. P1664/16, 33 (Fig. 3C), P2227/11.

\section{Quercus ?gigas Göppert emend. Walther \& Zastawniak Figure 3M}

1993 Quercus czeczottiae Hummel 1983. - Schweigert, p. 66 , partim, non pl. 2, fig. 1 .

Material. - P1666/3.

Figure 5. A-D - Celtis japeti Unger; A - P1648/1A; B - P1648/1B; C - P1648/2; D - P1652/1. • E - cf. Celtis japeti Unger, P1243/7. • F-H - Zelkova zelkovifolia (Unger) Bůžek \& Kotlaba; F - P1655/1; G - P1655/10; H - P1655/16. • I - "Parrotia" pristina (Ettingsh.) Stur, P1649/1. • J - ?Carpinus sp., P1676/1. • K - Acer tricuspidatum Bronn vel A. angustilobum Heer, P1653/1. • L - Acer pseudomonspessulanum Unger emend. StröbitzerHermann vel Acer integrilobum Weber sensu Walther, P1653/2. • M - Populus balsamoides Göppert, P1669/1. Scale bar $=10 \mathrm{~mm}$. 


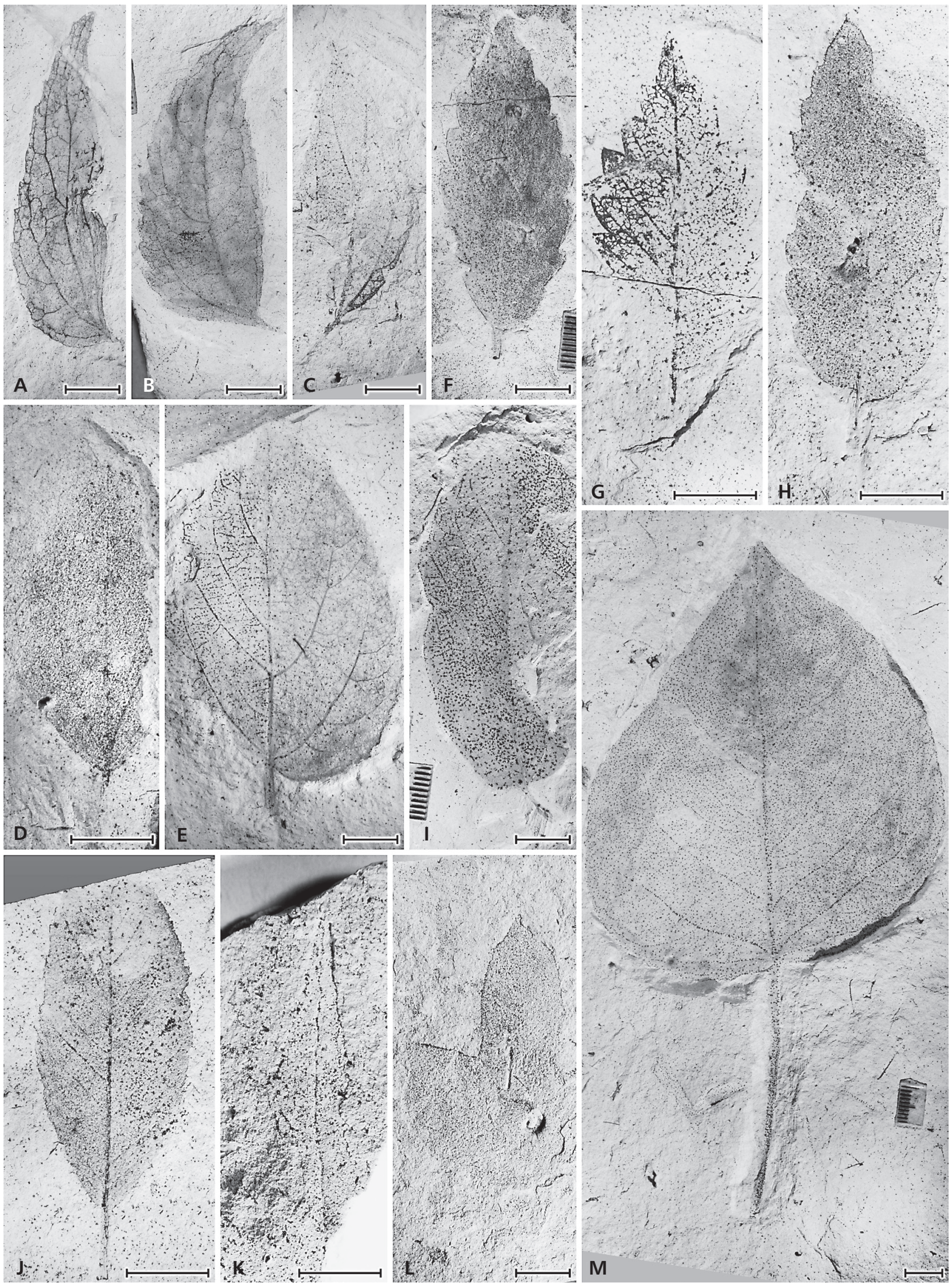


Description. - Leaf fragment of a large blade lacking base, apex and margin; $1 \times \mathrm{w}=70 \times 40 \mathrm{~mm}$ (both length and width incomplete); midvein almost straight, secondaries arising at about $45-50^{\circ}$, secondary vein spacing $5-9 \mathrm{~mm}$, rather regular, directly after their origin approaching the midvein (right side), otherwise straight, almost parallel and somewhat diverging towards the margin; tertiaries percurrent/mixed opposite to alternate (forked) percurrent, angle to midvein obtuse.

Remarks. - Although this specimen is rather incomplete, the secondary venation and tertiaries clearly point to Quercus. The size of the blade and the relatively dense secondary spacing are indicative of $Q$. gigas. In $Q$. pseudocastanea the distance between secondaries is usually wider.

\section{Quercus kubinyii (Kováts ex Ettingsh.) Czeczott}

Figure 3P, Q

1856 Castanea kubinyii Kov.; Kováts, p. 25, pl. 3, figs 1-7. 1951 Quercus kubinyii (Kov.) comb. nov. - Czeczott, p. 368. 1983 Zelkova praelonga Berger. - Gregor, p. 14, pl. 1, fig. 4. 1993 Quercus czeczottiae Hummel 1983. - Schweigert, p. 66 , partim, pl. 2, fig. 1 .

1993 Zelkova zelkovaefolia (Unger) Bůžek et Kotlaba in Kotlaba 1963. - Schweigert, p. 69, partim, (P1243/3), non pl. 3, fig. 1 .

Material. - P1243/3; P1666/1 (Schweigert 1993, pl. 2, fig. 1).

Description. $-\mathrm{P} 1243 / 3$ : Petiole almost straight, $7 \mathrm{~mm}$ long, $1 \times \mathrm{w}=38 \times 13 \mathrm{~mm}$, ratio $1 / \mathrm{w}=2.9$, laminar shape ovate, base shape convex, assymmetrical, base angle obtuse, margin simple serrate, teeth regularly spaced, narrow, basal and apical side variable, apex acute to attenuate, sinus rounded to acute; midvein slender, somewhat sinuous, secondaries weakly preserved, simple craspedodromous, ending in the teeth apices.

P 1666/1: Petiole straight, $10 \mathrm{~mm}$ long, $1 \times \mathrm{w}=41$ (complete length?) $\times 29 \mathrm{~mm}$, laminar shape ?oblong or ?elliptic, base shape convex, base angle obtuse, margin simple serrate, teeth regularly spaced, narrow, sometimes hook-shaped, apices acute to acuminate, sinus wide, rounded, basal side straight to somewhat convex (only few teeth preserved); midvein straight, secondaries simple craspedodromous, originating at angles of about $40-50^{\circ}$ running straight to minimally recurved into the marginal teeth, tertiaries percurrent to forked percurrent, $4^{\text {th }}$ order veins can still be differentiated from $5^{\text {th }}$ order veins, both random reticulate.

Remarks. - Specimen P1666/1 (Fig. 3Q) differs from
Q. drymeja by the wide leaf base, the serration which starts shortly above the base and spinous teeth not apressed to the leaf margin. Specimen 1243/3 (Fig. 3P) is a tiny leaf not showing marginal serration characteristic of Zelkova as proposed by Gregor (1983) and Schweigert (1993) (see also Z. zelkovifolia).

\section{Quercus mediterranea Unger}

Figure $3 \mathrm{H}-\mathrm{L}$

1847 Quercus mediterranea; Unger, p. 114, pl. 32, figs 1, 7,9 , ?figs $5,6,8$.

1983 Quercus spec. (aff. Qu. mediterranea). - Gregor, p. 11, pl. 4 , fig. 9.

1993 Quercus mediterranea Unger 1847. - Schweigert, p. 67, pl. 2, fig. 2.

1993 Quercus czeczottiae Hummel 1983. - Schweigert, p. 66 , partim.

Material. - P1243/11 (Gregor 1983, pl. 4, fig. 9), P1666/2, P1678/1 (Schweigert 1993, pl. 2, fig. 2), 2, 5, 6, 8, ?9, 10-14, 16, 23, 24, 28; cf. P 1678/3, 15, 17, 21, 22, 25; P2227/9, 10, 20.

Description. - Probably coriaceous leaves, petiole often curved, relatively short, mainly up to $5 \mathrm{~mm}$, rarely up to $10 \mathrm{~mm}$ long, leaf base often somewhat asymmetric, base shape convex, sometimes slightly cordate, base angle wide acute to obtuse, apex rarely preserved, ?acute to slightly ?acuminate, laminar shape elliptic to obovate, $1 \times$ w mainly $30-50 \times 18-30 \mathrm{~mm}$, occasionally up to $? 60 \mathrm{~mm}$ long or small $(21 \times 15 \mathrm{~mm}, \mathrm{P} 2227 / 9)$, ratio $1 / \mathrm{w}$ $=1.4-2.2$; margin simple serrate, sometimes ?entire (P1666/2), teeth very narrow, spiny, sometimes slightly hook-shaped, sinus rounded, basal side mainly straight, apical side more variable, straight or concave, tooth spacing more or less regular, in distances of several $\mathrm{mm}$ also in small leaves; midvein straight, sometimes curved, apically sometimes slightly sinuous, secondaries arising at angles of up to at least $60^{\circ}$, apically steeper than basally, craspedodromous, secondaries often forking once, entering marginal teeth, tertiaries percurrent (rarely preserved), higher-order veins reticulate (P1678/1).

Remarks. -Although the presence of Q. mediterranea is undisputable in Steinheim, the differentiation of some specimens from other Quercus species remains ambiguous. Specimen P2227/9 (Fig. 3L) is a small leaf with relatively big teeth. Specimen P1666/2 (Fig. 3J), which is a relatively large-sized, well-preserved specimen, is ?devoid of teeth but otherwise matches Q. mediterranea.

\section{Quercus pseudocastanea Göppert}

Figure $4 \mathrm{P}-\mathrm{R}$ 
1852 Quercus Pseudo-Castanea Göpp.; Göppert, p. 74, pl. 35 , figs $1,2$.

1993 Quercus pseudocastanea Göppert 1852. - Schweigert, p. 657 , pl. 2, fig. 4 .

Material. - P1663/1 (Schweigert 1993, pl. 2 fig. 4), 2, cf. 3, 4 (counterpart to P1663/1).

Description. - Long-petiolate leaves, laminar shape oblong-obovate, $1 \times \mathrm{w}=$ up to at least (114) $120 \times 40 \mathrm{~mm}$, petiole $14 \mathrm{~mm}$ long, basally somewhat swollen, almost straight; base shape (narrow) rounded, base angle obtuse, apex narrow rounded, margin simple dentate/lobate, sinus rounded, apex rounded or shortly acute/acuminate, secondaries craspedodromous, regularly spaced at distances between $7-13 \mathrm{~mm}$, angle to midvein about $45^{\circ}$, near their origin converging to the midvein then curving towards the leaf margin (P1663/2), terminating in the tooth apices, tertiaries sinuous, percurrent to forked percurrent.

Remarks. - Although rare, Q. pseudocastanea is present at Steinheim. This makes it one of the earliest occurrences of roburoid oaks in western parts of Central Europe. Specimen P1663/3 is not characteristic and could also be grouped with $Q$. mediterranea.

\section{?Quercus sp.}

Figure 4A-M

1983 Tremophyllum integerrimum (Web.) Rüffle. - Gregor, p. 13, pl. 1, figs 2,3 .

1993 Quercus drymeja Unger 1847. - Schweigert, p. 66, partim, pl. 2, fig. 5 .

Material. - P1243/1, 2 (Gregor 1983, pl. 1, figs 2, 3); 1664/1 (Schweigert 1993, pl. 2, fig. 5), 11, 13, 15, ?17, 18-20, ?23, 24, 25, 31, 38-43, ?44, 45, 46, 48-51, 53, 54, 57.

Description. - Petiolate leaves, petiole up to $12 \mathrm{~mm}$ long and less than $1 \mathrm{~mm}$ wide, straight or curved, basally somewhat swollen; laminar shape slender, mainly slightly ovate, oblong or slightly elliptic, $1 \times \mathrm{w}=30-70 \times 9-15$ (rarely 19 ) $\mathrm{mm}$, ratio l/w $=3.3-5.6$; base shape often somewhat asymmetric, mainly (weakly) convex, in rare cases minimally truncate, base angle mainly obtuse, otherwise widely acute or acute, apex shape attenuate, apex angle narrow acute; margin simple serrate, teeth regularly spaced, one above each secondary vein, occasionally additionally a single tooth between two adjacent secondaries, basal side long, mostly convex, more rarely straight to apically minimally retroflexed, apical side very short, concave to straight, apex blunt to acute, hook-shaped, sinus rounded; midvein slender, often bent, secondaries mainly craspedodromous, rarely semicraspedodromous (P1664/1), rather closely and regularly spaced, 3-7 mm in the central part of the lamina, weakly curved or almost straight, sweeping upwards, mainly unforked, in rare cases forked (1664/48), intersecondaries sometimes present, tertiaries mainly random reticulate but exceptionally also percurrent (P1664/1).

Remarks. - This leaf type is common at Steinheim. The variety of determinations found on collection labels, including not only already published assignments (see synonymy) but also Zelkova praelonga and even Gleditsia lyelliana, reflects the difficulties to assign these leaves systematically.

Compared to Cedrelospermum - C. ulmifolium (Unger) Kovar-Eder, Kvaček (former Tremophyllum tenerrimum) (Hably \& Thiébaut 2002, Kovar-Eder et al. 2004), C. lineatum (Lesquereux) Manchester and C. nervosum (Newberry) Manchester, (Manchester 1989) - the leaves are larger, the length/width ratio is higher, the petiole is longer, the angle of the teeth apices is narrower and the apices are often slightly hook-shaped. Quercus drymeja from the type locality Parschlug (Unger 1850, KovarEder et al. 2004) as well as from other sites such as Kumi (Evia Island) and Vegora (Greece; Kvaček et al. 2002, Velitzelos et al. 2002) differs by bigger size of the blades, lower length/width ratio, longer petiole, mainly cuneate leaf base, serration starting in further distance from the leaf base, long attenuate teeth and less densely spaced secondaries. The foliage of Zelkova differs in wider leaf shape (lower length/width ratio), short petiole, less numerous secondaries and teeth, as well as in bigger tooth size and different tooth shape.

Morphologically, none of the modern oaks mentioned by Schweigert ( $Q$. libani, Q. serrata, Q. acutissima) may serve for comparison because their leaf physiognomy differs considerably from the fossil material. Currently, we are not aware of any modern oak species with closely resembling leaves. Only $Q$. handeliana A. Camus is similar in size $(1 \times \mathrm{w}=20-47 \times 7-15 \mathrm{~mm})$ (Menitsky 1984) but the secondaries and number of teeth are less numerous and the marginal serration starts higher up than in the leaves from Steinheim. These facts account for the hesitation to assign this fossil material unambiguously to Quercus.

Myricaceae

\section{Myrica sp.}

Figure 4N, O

1993 Lonicera studeri (Heer) comb. nov. - Schweigert, p. 78 , partim, pl. 3 , fig. 7 . 
Material. - P1668/3, ?6, 7.

Description. - Petiolate leaves, petiole $8 \mathrm{~mm}$ long (P1668/6), laminar shape obovate, $1 \times \mathrm{w}=34-53$ (about $55) \times 15-19 \mathrm{~mm}$, ratio $1 / \mathrm{w}=2.3-2.9$, base shape cuneate, base angle acute, apex shape straight to somewhat convex, utmost apex acute or acuminate, margin basally (?)entire, then more or less minutely serrate, sinus acute, apex (bluntly) acute, ?two teeth per interval between secondary veins; midvein straight to bent (P1668/6), secondaries probably (weakly) brochidodromous but very indistinct near the leaf margin, arising at about $\geq 45^{\circ}$, more rarely under steeper angles, ascending somewhat bent or almost straight towards the margin, secondary spacing $4-7 \mathrm{~mm}$ (P1668/3), some secondaries forked, intersecondaries present.

Remarks. - These leaves are very poor in contrast. The differentiation between Myrica and Quercus drymeja is a challenge if the leaf margin and marginal venation are unclear (see also paragraph $Q$. drymeja). The heredescribed specimens are evidently serrate in the apical half of the lamina, contrary to Schweigert's (1993) description, and bear more than one tooth per secondary vein and faint intersecondaries. These features point to Myrica because Q. drymeja usually bears one tooth above each secondary vein, its secondary venation is craspedodromous to weakly brochidodromous, and the intersecondaries are absent. Nevertheless, the assignment of specimen P1668/6 (Fig. 4O) to Quercus cannot be ruled out.

The here-described leaves share with Myrica studeri Heer [Heer 1856, pl. 70, figs 21-24, basionym of Lonicera studeri (Heer) Schweigert] only the overall laminar shape. Due to the cuneate leaf base and the marginal serration, the assignment to Lonicera (Schweigert 1993) is not plausible, nor may the here-described leaves be conspecific with Heer's Myrica studeri. The specific assignment, however, remains open.

Malpighiales

Salicaceae

\section{Populus balsamoides Göppert}

Figure 5M

1855 Populus balsamoides G.; Göppert, p. 23, pl. 5, 6.

1993 Populus balsamoides Goeppert 1855. - Schweigert, p. 70 , pl. 1 , fig. 1 .

Material. - P1669/1 (Schweigert 1993, pl. 1, fig. 1), cf. 2, $\mathrm{P} 2231 / 9$.

Description. - Long-petiolate leaves, petiole $62-64 \mathrm{~mm}$ long, straight or gently bent, laminar shape broad ovate,
$1 \times \mathrm{w}=110(113) \times 93 \mathrm{~mm}(\mathrm{P} 1669 / 1)$ and $61 \times 48(? 50)$ $\mathrm{mm}(\mathrm{P} 2231 / 9)$, ratio $1 / \mathrm{w}=1.2$, base shape widely rounded to minimally cordate (P1669/1) or truncate (P2231/9), base angle obtuse, apex shape straight to acuminate, apex angle acute, margin regularly minutely crenate/serrate, serration starting near the base, tooth apex and base rounded, basal and apical side straight to convex; main vein straight, secondary vein spacing irregular, wide, up to $18 \mathrm{~mm}$, secondaries weakly semicraspedodromous to brochidodromous, ascending in wide and smooth curves, forking and releasing abmedial veinlets which loop near the margin, occasionally intersecondaries present, tertiaries percurrent, sinuous.

Remarks. - Two specimens unambiguously document this poplar at Steinheim. Specimen P1669/2 is much more poorly preserved; therefore, its assignment remains more ambiguous.

Rosales

Cannabaceae

Celtis japeti Unger

Figure 5A-E

1852 Celtis japeti; Ung., p. 116, pl. 43, figs 25, 26.

? 1983 Byttneriophyllum tiliaefolium (Al. Br.) Knobl. \& Kvac. - Gregor, p. 16, pl. 2, fig. 4.

1993 Celtis begonioides Goeppert 1855. - Schweigert, p. 68, partim, pl. 3, fig. 4.

1993 Smilax weberi Wessel in Wessel et Weber 1855. Schweigert, p. 81, sine fig.

Material. - P1648/1 (Schweigert 1993, pl. 3, fig. 4), 2, cf. P1243/7 (Gregor 1983, pl. 2, fig. 4), P1652/1.

Description. - Petiolate, mainly strongly asymmetrical leaves, petiole up to $10 \mathrm{~mm}$ long at least, $1 \times \mathrm{w}$ up to 60-65 $\times 52 \mathrm{~mm}$, ratio $1 / \mathrm{w}=1-3.5$, base shape variable, rather straight, convex to somewhat cordate (P1243/7), base angle acute, obtuse (P1243/7), apex shape attenuate, often with one side convex the other concave, apex angle usually narrow acute, margin simple serrate, serration starting somewhat above the base, tooth apex sharply acute, sinus mainly acute, both basal and apical sides variable; midvein usually bent or straight (P1243/7), lowermost pair of secondaries originating directly at the base (basal acrodromous), secondaries rather widely spaced, angle of origin $<30^{\circ}$ to about $50^{\circ}$, semicraspedodromous, agrophilic, tertiaries sinuous, percurrent to forked percurrent, tertiary vein angle obtuse to almost perpendicular.

Remarks. - While the assignment of specimens P1648/1, 2 (Fig. 5A-C) is unambiguous, specimen P1243/7 (Fig. 5E) 
differs by bigger size, less asymmetrical laminar shape, slightly cordate base and minute serration. Specimen P1652/1 (Fig. 5D), formerly assigned to Cinnamomum (i.e. Daphnogene, handwritten label by Gregor) and later to Smilax sp. (Schweigert 1993), definitely bears teeth on the left side, though weakly visible, and, under oblique light, some details of the secondary and tertiary venation are discernable. This specimen doubtlessly represents C. japeti.

The differentiation of Celtis foliage from Parschlug (C. japeti Unger 1850), Sośnica (C. begonioides Göppert $1855)$ and from Tokay (C. trachytica Ettingsh. 1853) is highly ambiguous. The epitethon japeti, therefore, has priority (Kovar-Eder et al. 2004).

\section{Celtis lacunosa (Reuss) Kirchheimer}

Remarks. - See Gregor (1983).

Ulmaceae

\section{Zelkova zelkovifolia (Unger) Bůžek \& Kotlaba} Figure $5 \mathrm{~F}-\mathrm{H}$

1843 Ulmus zelkovaefolia; Unger, pl. 24, figs 7 (right), 9-13.

1963 Zelkova zelkovaefolia (Unger 1843) Bůžek et Kotlaba in Kotlaba 1963. - Kotlaba, p. 59, pl. 3, figs 7, 8.

non 1983 Zelkova praelonga Berger. - Gregor, p. 14, pl. 1, fig. 4.

1993 Zelkova zelkovaefolia (Unger) Bůžek et Kotlaba in Kotlaba 1963. - Schweigert, p. 69, partim, pl. 3, fig. 1.

Material. - P1655/1 (Schweigert 1993, pl. 3, fig.1), 5, 6, $10,11,15,16$.

Description. - Shortly petiolate leaves, petiolus up to $5 \mathrm{~mm}$ long and about $1 \mathrm{~mm}$ wide, often with dense horizontal wrinkles; laminar shape ovate, elliptic to obovate, small leaves sometimes almost orbicular, $1 \times \mathrm{w}=20-56 \mathrm{~mm}$, $\mathrm{w}=15-24 \mathrm{~mm}$, ratio $1 / \mathrm{w}=1.1-3.4$, base usually asymmetrical, base shape mainly convex, sometimes straight or at the very base concave, base angle obtuse or acute, apex shape straight, a bit convex or acuminate, apex angle acute to narrow acute, margin simple serrate, teeth rather big, only few teeth on each side of the lamina, basal side mainly convex, apical side variable, convex, straight to concave, sinus mainly acute, apex bluntly acute to rounded; midvein straight, secondaries arising at angles of $40-50^{\circ}$, slender, ascending straight or somewhat bent across the lamina, terminating in the tooth apices, tertiaries random reticulate.

Remarks. - Although leaves of this taxon are not numerous at Steinheim, they represent its characteristic vari- ability. Remarkable is the dense horizontal grooving on most specimens with preserved petiole. The thick and short petiole, leaf shape as well as the big marginal teeth are discriminant features compared to leaves of ?Quercus sp. The specimen assigned to Zelkova by Gregor (1983) and later included in Z. zelkovifolia by Schweigert (1993) definitely has to be excluded. Neither tooth shape nor the dense tooth spacing match Zelkova. Instead, this specimen likely represents a small leaf of Quercus kubinyii (see chapter Quercus kubinyii).

?Rosaceae

?Rosaceae gen. et sp. indet.

Figure 9J

1993 Rosa lignitica Heer 1869. - Schweigert, p. 71, pl. 5, fig. 2 .

Material. - P1651/1 (Schweigert 1993, pl. 5, fig. 2).

Description. - Simple, petiolate leaf, petiole bent, $5 \mathrm{~mm}$ long, laminar shape slightly obovate, $1 \times \mathrm{w}=40(42) \times$ $18 \mathrm{~mm}$, ratio $1 / \mathrm{w}=2.3$, base shape rounded, angle acute, apex shape acute to slightly acuminate, margin finely dentate or crenulate, midvein slender, almost straight, secondaries? semicraspedodromous, single secondaries weakly visible only, exmedial veinlets (originating from the secondaries) running towards the leaf margin.

Remarks. - This specimen is characterised by its minute marginal dentation/crenulation, which is not characteristic of Rosa but may occur among other Roscaceae. In Rosa the leaf margin is sharply serrate, lateral leaflets are usually (sub)sessile and the terminal one is straightly petiolulate.

This specimen resembles Dicotylophyllum heeri (Engelhardt) Kvaček \& Walther (Kvaček \& Walther 1998) and D. ungeri (Engelhardt) Walther \& Kvaček (Walther \& Kvaček 2007), for which the authors assume a possible Rosaceae affinity. Both, D. heeri and D. ungeri, have, however, been described from the Early Oligocene.

Sapindales

Sapindaceae

Acer pseudomonspessulanum Unger emend. StröbitzerHermann vel Acer integrilobum Weber sensu Walther Figure 5L

1993 Acer tricuspidatum Bronn 1838. - Schweigert, p. 75, partim.

Material. - P1653/2. 
Description. - Very faint impression of a probably threelobed palmate leaf, central lobe $45 \mathrm{~mm}$ long, near the apex somewhat constricted, one lateral lobe incompletely preserved, margin mainly entire, sinus between lobes acute, angle almost $90^{\circ}$; main veins slender, secondaries slender, alternate, arising on the central lobe at about $40-50^{\circ}$.

Remarks. - This leaf is too fragmentarily preserved for an exact specific assignment. Acer tricuspidatum Bronn definitely has to be excluded because the margin of that species is serrate.

\section{Acer tricuspidatum Bronn vel Acer angustilobum Heer} Figure 5K

1993 Acer tricuspidatum Bronn 1838. - Schweigert, p. 75, partim.

Material. - P1653/1.

Description. - Leaf fragment consisting of two elongated, narrow lobes, 60 and $30 \mathrm{~mm}$ long, respectively, base not preserved, apex shape of lobes straight, angle narrow acute, sinus between lobes ?rounded, angle about $50^{\circ}$; near the apex of the longer lobe, the leaf margin is finely, sharply serrate; main veins slender, secondaries alternate, curved, ?semicraspedodromous.

Remarks. - This fragment probably represents a palmate leaf. The marginal serration may point to $A$. tricuspidatum or A. angustilobum. This leaf differs not only by the marginal serration from the afore-described but also by the narrow shape of the lobes.

Rutaceae vel Simaroubaceae

\section{Chaneya oeningensis (Heer) Teodoridis \& Kvaček} Figure 3R

1847 Getonia oeningensis. - Unger, p. 140.

1993 Astronium oeningense (A. Braun) Iljinskaja et Akhmetiev, 1989. - Schweigert, p. 75, pl. 4, fig. 6.

2005 Chaneya oeningensis (Heer) comb. nov. - Teodoridis \& Kvaček, p. 98, pls 1, 2, pl. 3, figs 1-5.

Material. - P1657/1 (Schweigert 1993, pl. 4, fig. 6).
Description. - Pentamerous perianth, with indistinct remains of the gynoecium in the centre, corolla $22 \mathrm{~mm}$ in diameter, single petals about $10 \mathrm{~mm}$ long and $5 \mathrm{~mm}$ wide, shape elliptic to somewhat obovate, narrowing near the base, apex rounded, with distinct venation, several main veins arising at the base, running subparallel across the lobes, secondaries ascending steeply towards the apex, further veins forming areoles.

Remarks. - This single remain is rather well preserved and available from Steinheim as part and counterpart. The petal size matches well with that of Chaneya oeningensis, whereas C. membranosa (Göppert) Manchester \& Zastawniak (Sośnica, Poland, Late Miocene) differs by larger-sized petals. Accessorically, Chaneya occurs at different European sites (Teodoridis \& Kvaček 2005) and is known across the Northern Hemisphere. Its Rutalean affinity was discussed by Wang \& Manchester (2000); later, it was assigned to Rutaceae vel Simaroubaceae by Teodoridis \& Kvaček (2005), who favoured the Rutaceae relationship. Manchester \& Zastawniak (2007) assign it to the Rutaceae but discuss the systematic affinity of Chaneya again, stressing that molecular analysis places Rutaceae, Simaroubaceae along with Meliaceae closely adjacent within Sapindales. Manchester \& Zastawniak (2007) refer to similarities in the phytogeography of Ailanthus (Simaroubaceae) but stress that oldest European records of Chaneya derive from the Late Oligocene whereas Ailanthus is known already from the Eocene. This ongoing discussion about the systematic position of Chaneya within Sapindales is relevant in the context of the Steinheim assemblage, which yields numerous largesized leaflets and some remains of petiole and rhachis of large-sized compound leaves (see chapter ?Sapindales fam., gen. et sp. - Petiole and rhachis of compound leaf).

?Simaroubaceae

?Alanthus sp.

Figure 6C

1993 Ailanthus confucii Unger 1850. - Schweigert, 76, pl. 3, fig. 6 .

Material. - P1658/1 (Schweigert 1993, pl. 3, fig. 6).

Description. - Fragmentarily preserved infructescence

Figure 6. A, B, G-I - Sapindales fam., gen. et sp. 1; A - P1243/6; B - P1662/12; G - 1662/5; H - 1667/2; I - P1662/3. • F, J - ?Sapindales fam., gen. et sp. 1; F - P1672/1; J - MKM sine no. compound leaf. • C - ?Ailanthus sp., P1658/1. D , E - modern Ailanthus altissima; D - endocarp after removal of the enveloping samara; E - broken envelope showing the hierarchical venation pattern on the external surface and the smooth internal surface; the venation turns into strong parallel veins upon the wing (from Herbarium sheet Ailanthus altissima, L.J. Novara 8403, 31.12.1988, STU). If not noted otherwise, scale bar $=10 \mathrm{~mm}$. 


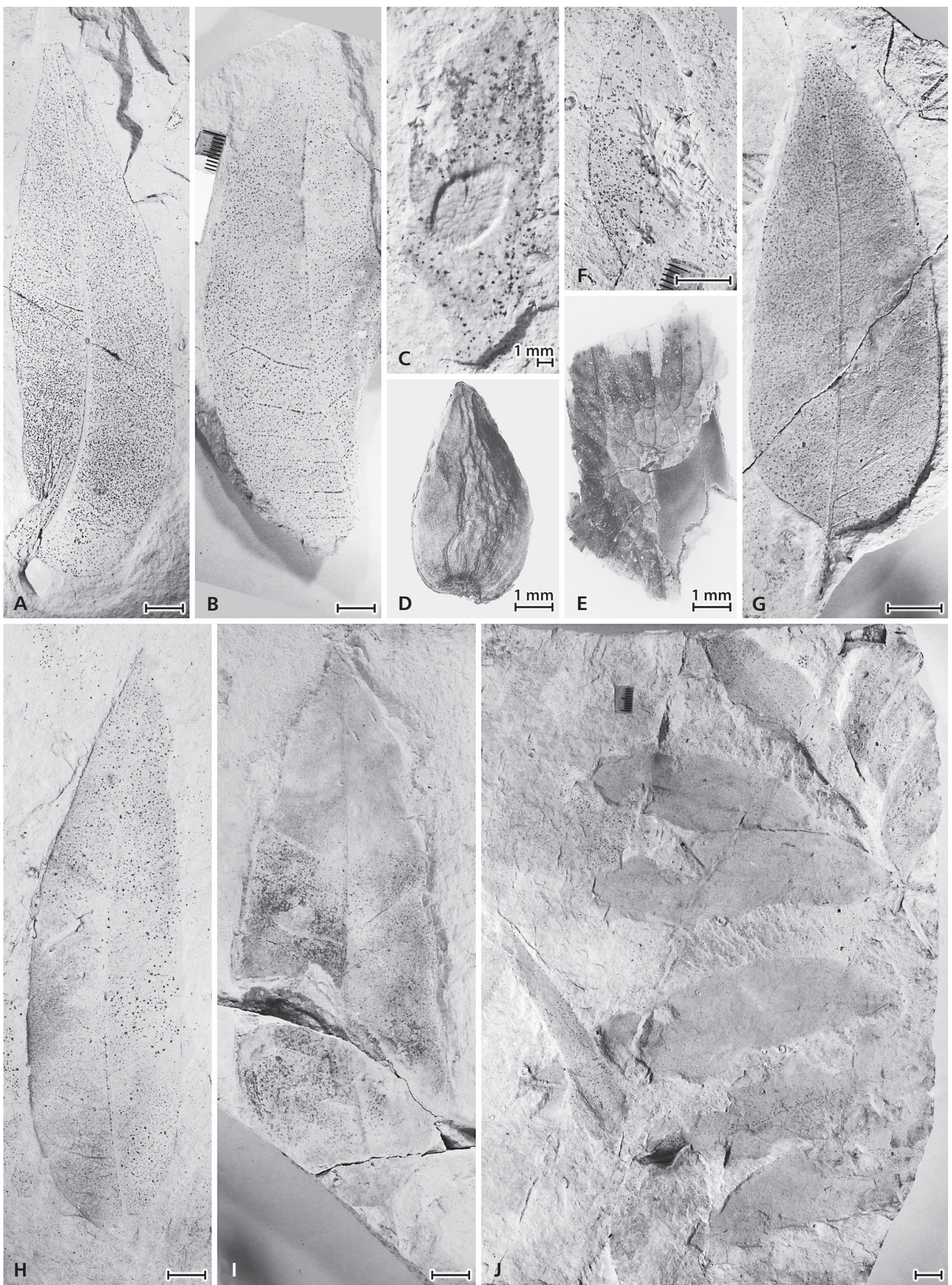


bearing a single endocarp; size $6 \times 4 \mathrm{~mm}$, endocarp oval, narrowed into a rounded apex, endocarp surface distinctly reticulate but not hierarchically organised; endocarp embedded by remains of a ?wing/envelope; a single vein discernable on the wing, paralleling the wing and entering the endocarp surface.

Remarks. - This specimen is not only incompletely preserved but covered by varnish, obviously applied to increase the contrast but obscuring the true outline of the ?wing/envelope. Schweigert's (1993) assignment was based on the reticulate surface and the surrounding structure, which he interpreted as wing. The discernable single vein, paralleling the wing/envelope and entering the endocarp, may represent the intramarginal ventral vein as it occurs in Ailanthus (Corbett \& Manchester 2004).

In modern Ailanthus altissima (Mill.) Swingle, wing tissue forms an envelope covering the endocarp. Upon the outer envelope surface, the venation forms a very distinct and hierarchically organised reticulum while the inner surface of the envelope is smooth. The venation continues in the same prominent manner on the wing but turning into rather parallel veins (Fig. 6E). Devoid the envelope (after mechanical removal), the endocarp shows a skin-like marginal edge, its base is broad, slightly retracted, showing sub-parallel folding in which the folds converge towards the insertion point of the funiculus, but is devoid of a reticulate structure (Fig. 6D). Comparing this situation with the fossil at hand, the surface of the endocarp should be interpreted as the outer surface of the envelope. In the fossil specimen, the reticulate pattern is not hierarchically organised and the structure surrounding the fossil endocarp does not bear the characteristic vein pattern present in modern Ailanthus. The generic assignment remains, therefore, ambiguous.

\section{Sapindales}

The Steinheim assemblage includes numerous specimens likely representing entire-margined leaflets of compound leaves of probable Sapindalean affinity. The systematic resolution of such fossil foliage is a general problem (not only restricted to Steinheim) for several reasons: Both intraspecific leaf and leaflet variability need to be taken into account, while the fossil record rarely contains compound leaves. Instead, leaflets are common or, respectively, their fragments. Within several families, different genera bear entire-margined compound leaves, e.g. Sapindaceae Sapindus, Koelreuteria, Simaroubaceae - Picrasma, Meliaceae - Cedrela, Toona, Rutaceae - Zanthoxylum, Fagaropsis, to mention a few. Finally, cuticles, which may contribute to a better systematic resolution, have been reported only rarely. For further discussion on this matter we refer to Walther (1999). The poor preservational state of the Steinheim material is unsuitable for better resolution. Therefore, only morphotypes are characterised here.

\section{Sapindales fam., gen. et sp. 1}

Figure 6A, B, F-J, 7A, B

1983 Persea princeps (Heer) Schimper. - Gregor, p. 14, partim.

1983 Sapindus falcifolius A. Br. - Gregor, p. 15, pl. 1, ?figs 1 , 6, pl. 2, fig. 3.

1993 Juglans acuminata A. Braun 1845. - Schweigert, p. 78, partim, pl. 1, fig. 2.

1993 "Sapindus" falcifolius A. Braun. - Schweigert, p. 73, partim, non pl. 1, fig. 3.

? 1993 Zanthoxylum sp. - Schweigert, p. 77, pl. 3, fig. 2.

Material. - P529/2, P1243/4 (Gregor 1983, pl. 1, fig. 6), 6 (Gregor 1983, pl. 2, fig. 3), P1662/1 (Schweigert 1993, pl. 1, fig. 2), 3, 5-8, 11-13, 15, 19, 20, 25-27, 30, 32, 36, 38, 38 X, 40-43, 45, 46; P1667/2, 9, 10, 12, 26; cf. P1667/3, 5, 11, 17, 22; ?P1672/1 (Schweigert 1993, pl. 3, fig. 2); ?MKM sine no. compound leaf (counterpart in MKM).

Description. - Large, long petiolate leaves or leaflets, petiole/petiolule up to $20 \mathrm{~mm}$ long, mainly straight, basally sometimes slightly widened, laminar shape ovate, oblong somewhat asymmetrical to almost symmetrical, rather variable in size, $1 \times \mathrm{w}=80-140 \times 25-60 \mathrm{~mm}$, ratio $1 / \mathrm{w}=2.4-4$, base shape rounded or convex, more or less asymmetrical, base angle obtuse, apex shape straight, utmost apex sometimes long acuminate, apex angle (narrow) acute, margin entire to slightly undulate, midvein distinct, straight to gently bent, secondaries delicate, mostly faintly if at all visible, ascending smoothly and in wide curves, weakly brochidodromous, secondary spacing (6) 8-15 (17) $\mathrm{mm}$, dehiscence angle of secondaries (45) $50-70^{\circ}$, intersecondaries occasionally present, short, tertiaries random reticulate to weakly percurrent, only exceptionally visible.

MKM sine no.: Fragment of a large, imparipinnate leaf, with at least 5 pairs and a terminal leaflet; leaflets already detached except for terminal one; leaflet shape elliptic to somewhat ovate or obovate, base angle wide acute, apex?, secondary spacing up to $8 \mathrm{~mm}$.

Remarks. - This foliage is rather distinct in the Steinheim assemblage due to its large-sized blades. The somewhat asymmetrical shape points to leaflets rather than leaves. If this assumption is correct, the compound leaves must have attained considerable size.

Specimen MKM sine no. (Fig. 6J) assigned to Sapindus falcifolius A. Br. by Gregor (1983) and included into Juglans acuminata by Schweigert [1993, specimen 
"1 Beleg o. Nr. (Dauerleihgabe Gemeinde Steinheim)"] represents an imparipinnate leaf. Its leaflets differ in so far as the base angle is narrower and the secondary spacing is closer. Possibly it represents a relatively smaller compound leaf of this type and therefore did not fall apart completely prior to sedimentation.

Schweigert's (1993) Zanthoxylum sp. was based on a single specimen (P1672/1, here Fig. 6F). Except for the smaller size, this specimen matches the here-described foliage rather well. It may simply represent a leaflet of a smaller blade or the smaller basal leaflet of a compound leaf.

Schweigert's assignment of most of the here-summarised material to Juglans acuminata was based on Juglans acuminata Heer (1859). The specimens figured by Heer $(1859$, pl. 128 , figs. $2,5,6,8)$ are distinctly petiolate and closely resemble the specimens from Steinheim. In Juglans the leaflets are very shortly petiolate to sessile and the tertiary venation is percurrent. Already Knobloch \& Kvaček (1976) excluded Heer's plate 128 from J. acuminata. Later, Iljinskaya (1994) proposed the new combination Cedrela acuminata (A.Br.) Iljinskaja for J. acuminata (Heer 1859, pl. 128, figs 3, 6, 8). Cedrela sarmatica (Kovács, 1957) resembles the Steinheim material including the random reticulate tertiaries (Kovács 1957, p. 440: "reticulum irregularem formantes") though these leaflets are shortly petiolate. Moreover, the generic assignment to Cedrela may be disputable. To conclude, this type of foliage is likely of Sapindalean affinity. Large pinnate, sometimes distinctly petiolate leaflets do occur in different families of the Sapindales (see above). A more precise scientific assignment of this material is, however, currently not possible.

\section{Sapindales fam., gen. et sp. 2}

Figure $7 \mathrm{C}-\mathrm{G}$

1993 Pistacia miochinensis Hu \& Chaney 1940. - Schweigert 1993, p. 75, pl. 3, fig. 5.

1993 "Sapindus" falcifolius A. Braun 1845. - Schweigert, p. 73 , partim, pl. 1, fig. 3 .

Material. - P1665/1 (Schweigert 1993, pl. 3, fig. 5), ?2, 3, ?4, 5; P1667/1 (Schweigert 1993, pl. 1, fig. 3), 15, cf. 21, 23, 27, 29; P2227/14, 15.

Description. - Subessile to shortly petiolulate, distinctly asymmetrical leaflets, laminar shape slender oblong (minimally ovate, elliptic or obovate), $1 \times \mathrm{w}=41-87 \times$ $10-20 \mathrm{~mm}$, ratio $1 / \mathrm{w}=4$ up to at least 4.5 , petiolule up to $5 \mathrm{~mm}$ long, base shape distinctly asymmetrical, one side often straight while the other convex, base angle acute, apex shape often straight to slightly acuminate, apex angle narrow acute, margin entire; midvein mainly straight, secondaries brochidodromous, delicate, angle of origin $>45^{\circ}$, secondary spacing $4-8 \mathrm{~mm}$ in the central part of the lamina, secondaries curving slightly sinuous upwards, forking at least once or give rise to looping abmedial veins, intersecondaries present.

Remarks. - Specimens P1665/1 and P1667/1 (Fig. 7E, G) are complete but hardly show venation details, contrary to specimens P1665/3 and 5 (Fig. 7D), which are less complete, yet bear visible secondary venation. Further specimens assigned by Schweigert (1993) to "Sapindus" falcifolius (no P1667/) and to Pistacia miochinensis (P1665/6) and not listed under "Material" here, largely lack diagnostic features, and specimen P1665/7 is petiolate: all are therefore not included.

Sapindales fam., gen. et sp. 2 differs from the aforedescribed taxon by smaller size, distinct asymmetry, especially of the base, higher $1 / \mathrm{w}$ ratio, short or absent petiolule, the rather straight shape and acute angle of the base as well as the delicate and irregularly sinuous secondaries. It resembles "S." falcifolius but the poor preservational state hinders a more precise assignment.

?Sapindales fam., gen. et sp. - Petiole and rhachis of compound leaf

Figure 8G, H, J

1993 Isoëtes sp. - Schweigert, p. 64.

Material. - P1671/2; ?P1671/1, 3.

Description. - Specimen 1671/2: Petiole and rhachis, $150 \mathrm{~mm}$ long (incomplete), petiole basally swollen $(6 \mathrm{~mm})$ into an oblique pulvinus, petiole tapering (3-2 $\mathrm{mm}$ ) into the rhachis, rhachis basally about $2 \mathrm{~mm}$ wide, gradually further tapering along length, gently bent, with opposite to sub-opposite abcission marks of leaflets at distances of 23-28 mm.

Specimen P1671/1: Petiole and incomplete rhachis, $180 \mathrm{~mm}$ long, petiole basally widened into a somewhat oblique pulvinus, $15 \mathrm{~mm}$ wide, petiole and rhachis tapering, 6-3 $\mathrm{mm}$ wide.

Remarks. - None of the here listed remains show a central vein as is known from Isoëtes.

The presence of abcission marks accounts for the undisputable identification of specimen $\mathrm{P} 1671 / 2$ as petiole and main axis of a compound leaf (Fig. 8G, H). Specimen P1671/1 (Fig. 8J) is even thicker, the presence of leaflet scars is disputable there. P1671/3 is the basal fragment of a very similar petiole. In the Steinheim collection of SMNS, further uninventoried specimens of leaf petioles with a pulvinus were found labeled as Isoëtes. 
The Steinheim assemblage includes numerous more or less large leaflets assigned here to Sapindales fam., gen. et sp. 1 and 2. Especially in Sapindales fam., gen. et sp. 1, the whole blades must have attained considerable size, while blades of Sapindales fam., gen. et sp. 2 were probably smaller. Possibly, the here-described fossils represent the central axes of Sapindales blades. In Podocarpium podocarpum, leaflet spacing is closer due to the small leaflet size, and the rhachis (and petiole) are more slender.

Incertae sedis

\section{Dicotylophyllum sp. 1}

Figure 9I

1983 Dicotylophyllum sp. (Sapotaceae?). - Gregor, p. 17, partim, non pl. 1, fig. 5, non pl. 2, fig. 1.

1993 Leguminosites sp. - Schweigert, p. 79, partim, pl. 4, fig. 5.

Material. - P1677/1 (Schweigert 1993, pl. 4, fig. 5), 2, 4, 5, 9-12; ?P1677/3, 7, 8, 13, 14, 16.

Description. - Small, petiolate, entire-margined, symmetrical leaves, $1 \times \mathrm{w}=20-45 \times 7-20 \mathrm{~mm}$, ratio $1 / \mathrm{w}=$ $2-2.7$, laminar shape obovate to elliptic, base cuneate (base shape straight, angle acute), apex more or less distinctly emarginate; midvein straight, secondaries only rarely visible (P1677/3), rather widely spaced compared to the small size of the blade: $7-8 \mathrm{~mm}$, steeply ascending, angle of origin $<30^{\circ}$.

Remarks. - The venation is visible in a specimen lacking the apex (P1677/3, Fig. 9I). Therefore, its assignment to this group is somewhat ambiguous. Schweigert (1993) considers leaves and leaflets for these specimens though they are petiolate and symmetrical, thus lacking features indicative of leaflets. Gregor (1983) described Dicotylophyllum sp. (?Sapotaceae). Unfigured specimens in the SMNS collection determined by Gregor belong to this group but both figured ones are to be excluded. They are too large and the apex seems incomplete (Gregor 1983, pl. 1, fig. 5) or rounded (pl. 2, fig. 1).

\section{Dicotylophyllum sp. 2}

Figure 9E

1859 Robinia Regeli. - Heer, p. 99, pl. 132, figs 20-26, non 34-41.
1993 "Robinia" regeli Heer 1859. - Schweigert, p. 73, pl. 4, fig. 4.

Material. - P1654/1 (Schweigert 1993, pl. 4, fig. 4).

Description. - Orbicular, symmetrical, tiny leaf, lacking petiole, $1 \times \mathrm{w}=12 \times 13 \mathrm{~mm}$, base shape slightly rounded, base angle wide obtuse, apex shape convex, utmost apex emarginate, margin probably entire, midvein straight, on each side of the midvein five secondaries smoothly ascending across the lamina, dehiscence angle wide at the base, narrower towards the apex.

Remarks. - The assignment not only to Robinia is ambiguous, as has been recognised by Schweigert (1993), but also that to the Fabaceae. Nothing points to the nature of a leaflet instead of a leaf. Lacking evidence of physical connection, the pods included in this fossil species by Heer (1859, pl. 132, figs 35-41) have to be separated.

\section{Dicotylophyllum sp. 3}

Figure 9K

1993 Populus mutabilis Heer 1856. - Schweigert, p. 70, pl. 3 , fig. 3.

Material. - P1656/1 (Schweigert 1993, pl. 3, fig. 3).

Description. - Petiolate leaf, petiole $2 \mathrm{~mm}$ long, incomplete, laminar shape broad elliptic, somewhat asymmetrical, $1 \times \mathrm{w}=55(? 56-58) \times 34 \mathrm{~mm}$, ratio $1 / \mathrm{w}$ about 1.7 , base shape slightly rounded, base angle wide acute, apex shape rather straight, apex angle acute, uppermost apex ?rounded, margin with few small and smoothly rounded teeth in the apical half on the right side and one tooth near the apex on the left side; midvein straight, secondaries vaguely preserved, ascending in wide curves across the lamina, probably weakly brochidodromous, ?8 secondaries on the right side of the lamina.

Remarks. - The fact that the basal secondaries do not differ from the others argues against the assignment to P. mutabilis (Schweigert 1993); in Populus these secondaries are usually stronger. Furthermore, in Populus the secondary vein spacing is relatively wide and thus the number of secondaries is low, while the specimen at hand shows at least 8 pairs of secondaries. The other specimens listed by Schweigert (1993) were not detected in the collection of SMNS. An assignment to Vitaceae (terminal

Figure 7. A, B - Sapindales fam., gen. et sp. 1, P1662/7; B - venation details. - C-G - Sapindales fam., gen. et sp. 2; C - P1665/4; D - 1665/5; E - P1665/1; F - P1667/23; G - P1667/1. • H-J - Dicotylophyllum sp. 4; H - P1662/9A; I - P1662/16; J - P1662/2A. Scale bar $=10 \mathrm{~mm}$. 


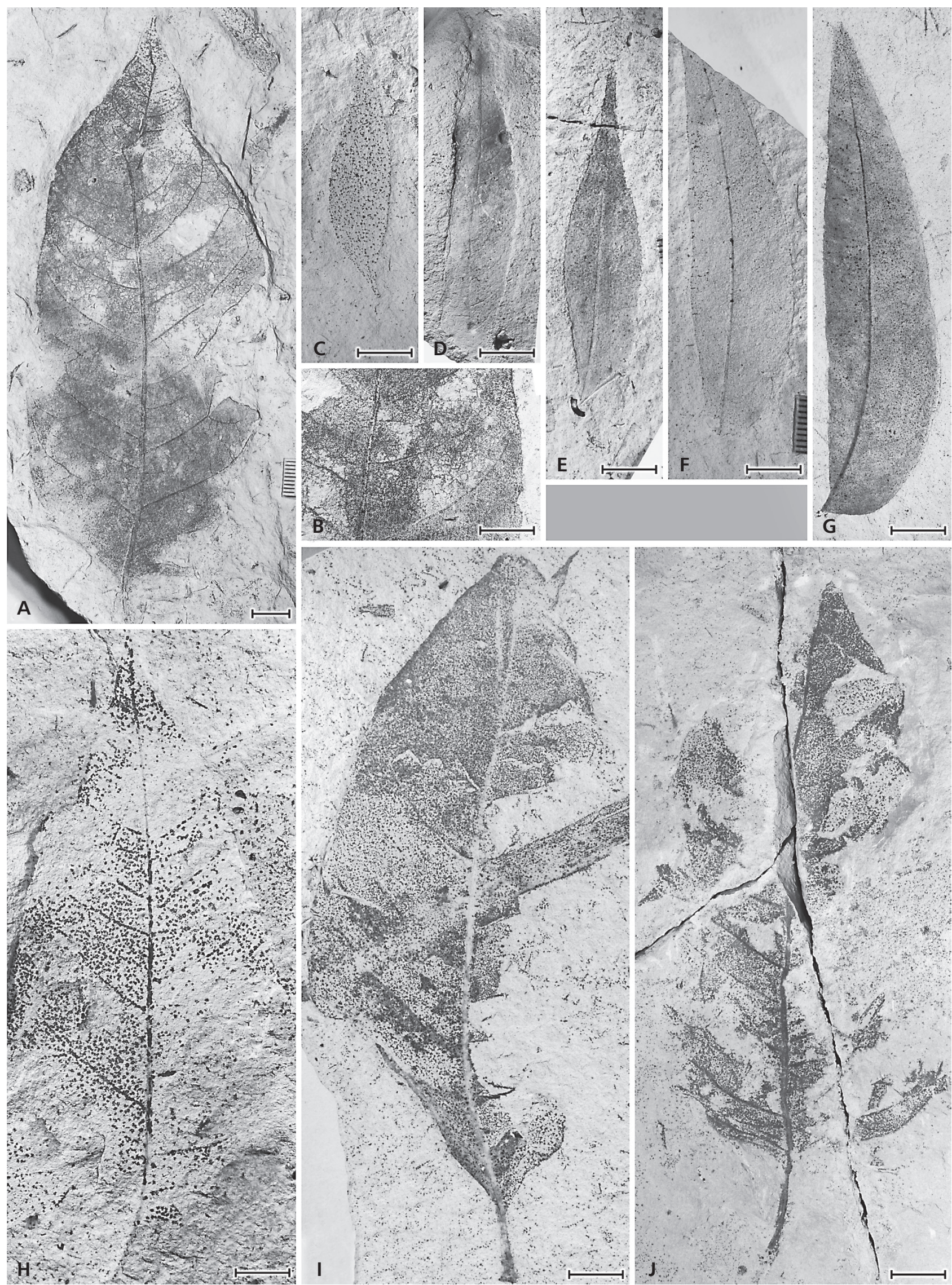


leaflet of a compound leaf) appears more reasonable though still ambiguous.

\section{Dicotylophyllum sp. 4}

Figure 7H-J

1983 Persea princeps (Heer) Schimper. - Gregor, p. 14, partim.

1993 Juglans acuminata A. Braun 1845. - Schweigert, p. 78, partim.

Material. - P1662/2, 9, 16.

Description. - Long-petiolate leaves, petiole 14 and $16 \mathrm{~mm}$ long, straight or slightly bent, swollen at the base (pulvinus), laminar shape broad ovate to elliptic, rather symmetrical, $1 \times \mathrm{w}=115(? 120)-117(? 125) \times 50-35$ (52) $\mathrm{mm}$, ratio $1 / \mathrm{w}$ about 2.4; base shape rounded, in the lowermost part concave, angle obtuse (P1662/2) and base shape straight, angle acute (P1662/16), apex shape straight to somewhat acuminate, angle acute, margin entire, slightly undulate (P1662/16); midvein straight or gently bent, secondaries ascending in wide curves, angle of dehiscence $>45^{\circ}$, ?brochidodromous, intersecondaries ?present, likely in P1662/2.

Remarks. - These leaves differ from Sapindales fam., gen. et sp. 1 by their rather symmetrical and broader ovate to elliptic shape $(1 \times \mathrm{w}=2.4)$ and the swollen petiole. The assignment to any Lauraceae (Gregor 1983) must definitely be rejected, and that to $J$. acuminata (Schweigert 1993) is very unlikely for this foliage due to the deltoidic laminar shape which, instead, is reminiscent of Populus. Diagnostic features are, however, too poor for a systematic assignment.

\section{Dicotylophyllum sp. 5}

Figure 9L

1993 Lonicera studeri (Heer) comb. nov. - Schweigert, p. 78 , partim.

Material. - P1668/2.

Description. - Petiolate, most likely coriaceous leaf, petiole at least $4 \mathrm{~mm}$ long, about $1 \mathrm{~mm}$ thick, basally somewhat swollen, angular to the midvein, laminar shape broad elliptic, $1 \times \mathrm{w}=40 \times 26 \mathrm{~mm}$, ratio $1 / \mathrm{w}=1.5$, base cuneate, base angle acute, apex shape rounded, apex angle obtuse, uppermost apex missing, margin simple serrate, teeth widely spaced, narrow, distinct but tiny, midvein straight, secondaries not preserved.

Remarks. - The thick petiole and the wide elliptic shape of this probably coriaceous leaf characterise this specimen and distinguish it from those described here as Myrica sp. and Dicotylophyllum sp. 6, both formerly assigned to Lonicera studeri by Schweigert (1993).

\section{Dicotylophyllum sp. 6}

Figure 9M

1993 Lonicera studeri (Heer) comb. nov. - Schweigert, p. 78 , partim.

Material. - P1668/4.

Description. - Leaf lacking petiole, laminar shape asymmetrical, ovate, $1 \times \mathrm{w}=34(35) \times 17 \mathrm{~mm}$, ratio $1 / \mathrm{w}=$ 2.1 , base shape rounded, base angle obtuse, apex shape rather straight, at the uppermost apex acuminate, apex angle acute, margin entire; midvein straight, secondaries delicate, brochidodromous, ascending at angles $\leq 45^{\circ}$, near the leaf margin forming elongated, narrowing and somewhat acute loops with the adjacent secondary vein.

Remarks. - The shape of the looping secondaries forming elongated, narrowing and acute meshes is characteristic of this leaf remain. It differs not only by this peculiar venation pattern but also by the ovate and somewhat asymmetrical laminar shape from the leaves that were previously ascribed to Lonicera studeri by Schweigert (1993).

\section{Dicotylophyllum sp. 7}

Figure 9H

1993 Dikotylenrest (Phyllocladium) gen. et sp. indet. Schweigert, p. 79, pl. 5, fig. 3.

Material. - P1679/1 (Schweigert 1993, pl. 5, fig. 3).

Description. - Basal fragment of a slender leaf, petiole incomplete, $1 \mathrm{~mm}$ long, blade fragment $16 \mathrm{~mm}$ long, complete length?, $5 \mathrm{~mm}$ wide, on both sides distinctly

Figure 8. A - Leguminosites cf. hesperidum (Unger) Kovar-Eder \& Z. Kvaček, P1661,1. • B-F, I - Podocarpium podocarpum (A. Braun) Herendeen; B - fragment of a compound leaf, P1660/113; C - fragment of a compound leaf, P1660/116; D - isolated leaflet, P1660/93; E - isolated leaflet, P1660/27; F - petiolate pod, P1659/2; I - isolated leaflet, P1660/86. • G, H - ?Sapindales fam., gen. et sp. - Petiole and rhachis of compound leaf, with abcission marks of leaflets; H - detail of G, P1671/2. - J - ?Sapindales fam., gen. et sp. - Petiole and rhachis of compound leaf, base developed as pulvinus, P1671/1. $\bullet \mathrm{K}$ - twig with brachyblasts, P2227/4. $\bullet$ L - twig with buds or abcission marks, P2227/7. $\bullet \mathrm{M}-$ spiny branch, P2216/1. Scale bar $=10 \mathrm{~mm}$. 


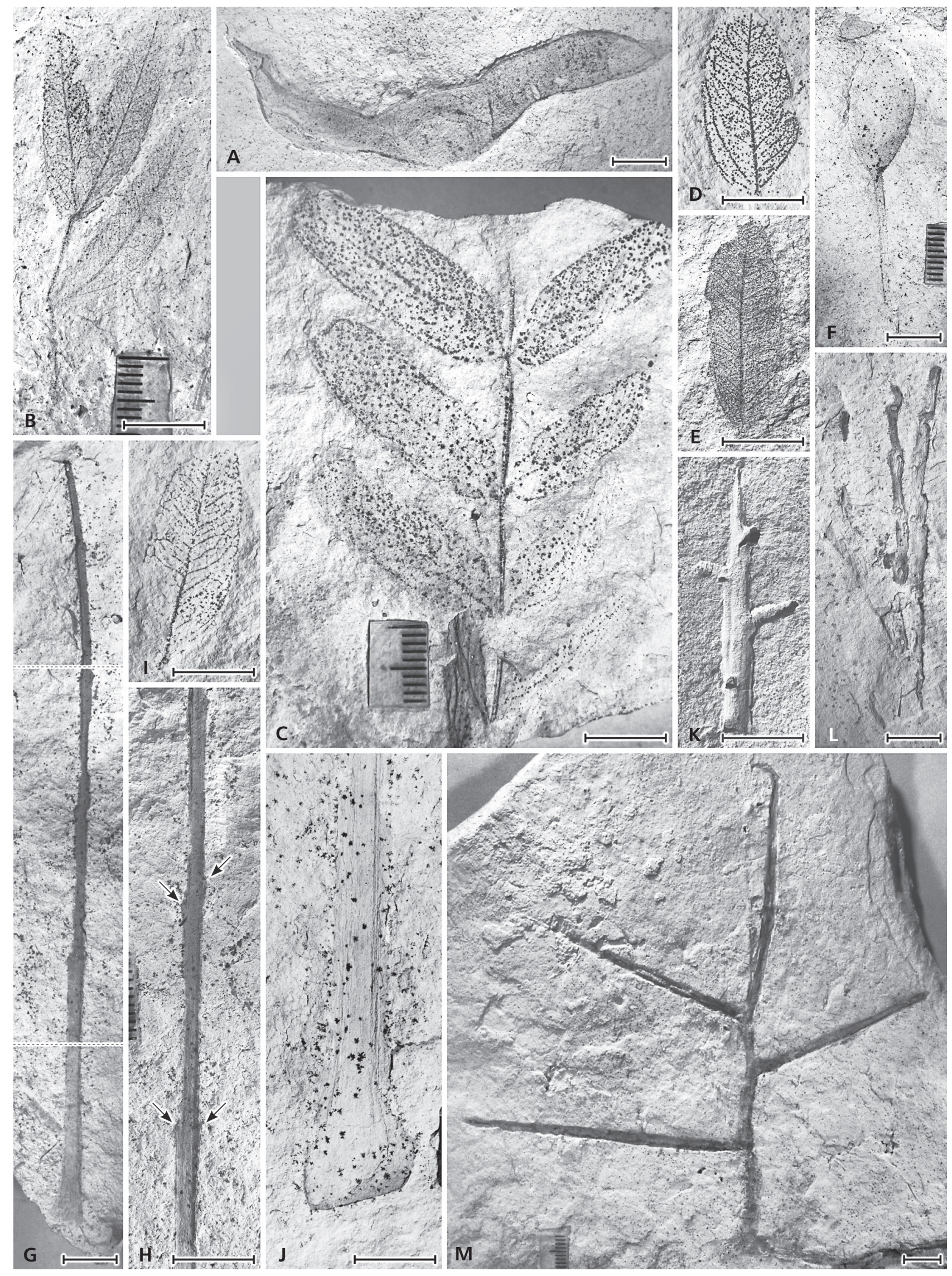


constricted, constrictions situated almost opposite to each other.

Remarks. - Contrary to Schweigert's (1993) view, the lateral constrictions may be caused by leaf damage already during leaf development, resulting in their opposite position. Similar contractions occur, in aberrant Myrica foliage for example.

\section{Dicotylophyllum sp. 8}

Figure 9F

Material. - P2227/6.

Description. - Ovate-elliptic leaf, $1 \times \mathrm{w}=95 \times 37 \mathrm{~mm}$, ratio $1 \times \mathrm{w}=2.6$, base shape concave, base angle acute, apex shape straight, apex angle acute, margin probably entire except for a distinct single lobe in the upper third of the right side, length and apex of the lobe not preserved, sinus rounded; midvein straight, otherwise only the main vein entering the lateral lobe is visible, arising about $35 \mathrm{~mm}$ above the base, angle of origin about $35^{\circ}$.

Remarks. - This specimen was found determined as Populus mutabilis and was only inventoried in the course of this study. The single lateral lobe accounts for the asymmetry of this blade, which is rather large compared to most of the material from Steinheim. Similar asymmetrical leaves do occur in Sassafras and Nyssa. In Sassafras the shape of the lobes are usually convex, thus different from the here-described specimen. Due to the scarcity of charcteristics, this leaf remains unassigned taxonomically.

\section{Phyllites sp. - ?floating leaf}

Figure 9C

Material. - P2227/13.

Description. - Petiolate, flabellate blade, petiole $11 \mathrm{~mm}$ long, ?complete, leaf base shape concavo-convex, base angle wide obtuse, $1 \times \mathrm{w}=26 \times 50(60-70) \mathrm{mm}$, margin probably entire, veins generally delicate, several primary veins (at least 6) arising at the base, diverging and forking during their course across the lamina.

Remarks. - This specimen was found labeled "?Alangium sp.". It may also remind of Chaneya (side view, imper- fectly preserved), but the size exceeds markedly the variability of Chaneya (compare Teodoridis \& Kvaček 2005). More likely, it represents a floating leaf of unknown affinity. Fan-shaped leaves of Mikia (?Trapaceae) differ by a thick petiole, the dentate-crenate distal leaf margin, and probably thick primary veins (Kovar-Eder et al. 2002). In Limnobiophyllum (Arales) the leaf shape is subcircular and secondary and higher-order veins form a network (Kvaček 1995a). In Hydrochariphyllum Kvaček (Hydrocharitaceae) the laminar shape is suborbicular to reniform (Kvaček 1995b). The leaf venation also differs from that of the here-described specimen. More material would be desirable to more definitively determine whether this is a so far unknown aquatic plant.

\section{Spiny branch}

Figure 8M

Material. - P2216/1, P2227/16, 19.

Description. - Thorn-like twig fragments, tapering along their length; with thorns up to $70 \mathrm{~mm}$ long, alternately arranged (P2216/1), suboppositely arranged in P 2227/16.

Remarks. - Among the described taxa, spiny twigs do occur among the Fabaceae.

\section{Twig with brachyblasts}

Figure 8K

Material. - P2227/4.

Description. - Terminal twig fragment, $34 \mathrm{~mm}$ long, $3.5 \mathrm{~mm}$ wide in the lowermost part, quickly narrowing to a thorn-like apex, two alternately inserted brachyblasts in the bedding plane, 4 and $5.5 \mathrm{~mm}$ long, the upper one with a deepening at its base, two further deepenings along the twig.

Remarks. - The holes may derive either from spines or further brachyblasts. In the latter case the brachyblast arrangement would be helical. In the collection, this remain was labelled as Gleditsia.

\section{Twig with buds or abcission marks}

Figure 8L

Material. - P2227/7.

Figure 9. A, B - ?Lythraceae gen. et sp.; A - details of venation, P1667/25. • C - Phyllites sp. - ?floating leaf, P2227/13. • D - remain indet. formerly assigned to Eichhornia (Schweigert 1993), P1673/1. • E - Dicotylophyllum sp. 2, P1654/1.• F - Dicotylophyllum sp. 8, P2227/6. • G - ?Trapa sp., neck and corolla, P2227/1. • H - Dicotylophyllum sp. 7, P1679/1. • I - ?Dicotylophyllum sp. 1, P1677/3. • J - ?Rosaceae gen. et sp. indet., P1651/1. • $\mathrm{K}-$ Dicotylophyllum sp. 3, P1656/1. • L - Dicotylophyllum sp. 5, P1668/2. • M - Dicotylophyllum sp. 6, P1668/4. Scale bar $=10 \mathrm{~mm}$. 


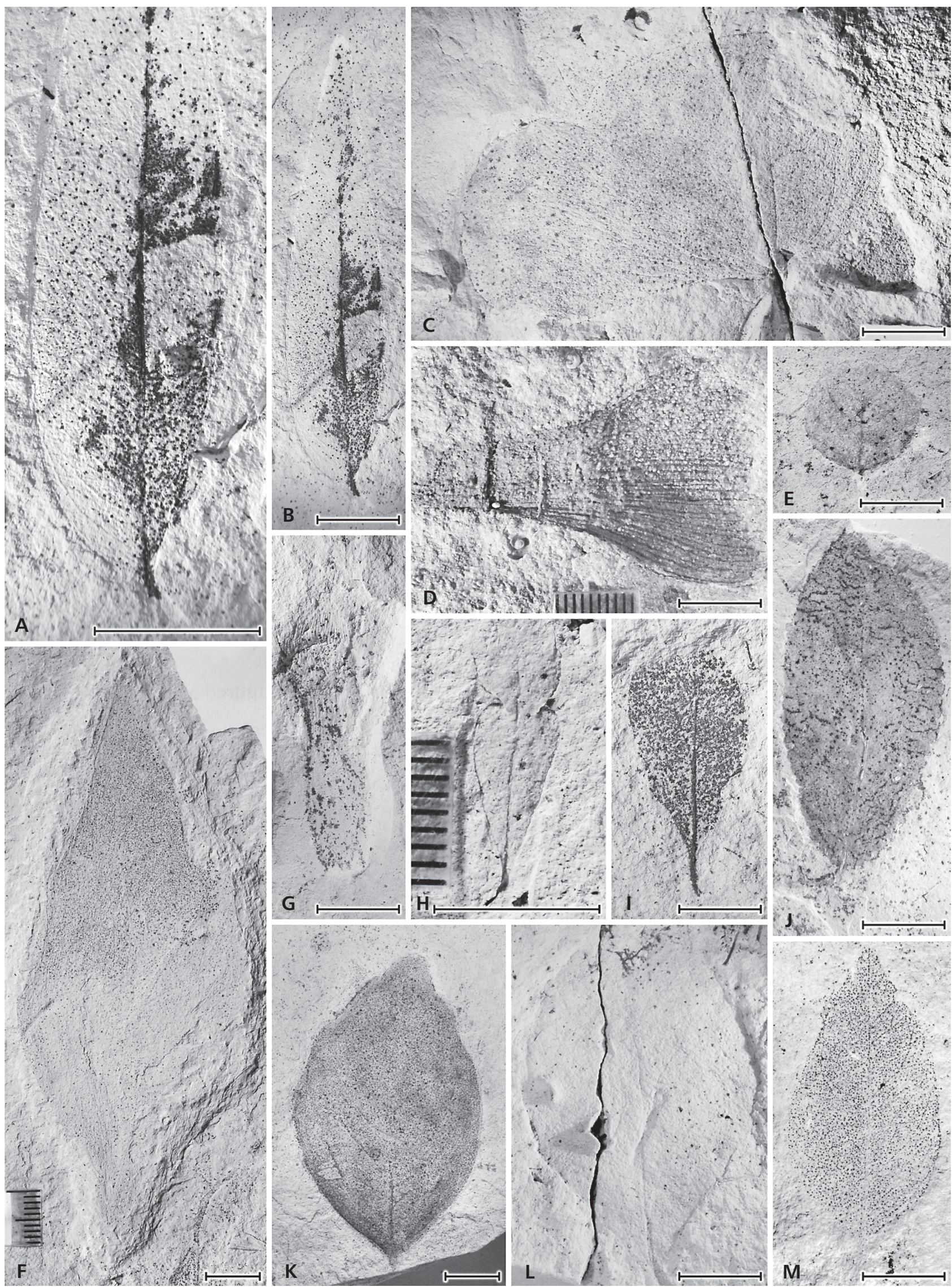


Description. - Pluri-branched twig, $60 \mathrm{~mm}$ at longest, surface ribbed, with numerous, helically arranged ?scars or ?buds; twig width undulate in which the scars or buds cause thickenings, whereas regions lacking scars are narrower, twig width 2-4 mm; scar shape round to elliptic, up to $1.5 \mathrm{~mm}$ at widest.

Remarks. - This is a further distinctive type of a woody branch. Its systematic affinity is open.

\section{Remain indet.}

Figure 9D

Material. - Specimen P1673/1 assigned to Eichhornia sp. (Schweigert 1993, pl. 5, fig. 5) is a robust remain of unknown affinity.

\section{Discussion}

\section{Taphonomy}

In the Steinheim impact crater the sediments lack evidence of surface influx (Janz 1992). Thus, quiet conditions are assumed and transport of plant debris probably played, if at all, a minor role. Except for ?Potamogeton geniculatus which sometimes covers bedding planes, plant remains occur only sporadically, neither being concentrated in lenses nor in beds. Shoot bases of Equisetum sp. (Fig. 2E) and rhizome fragments of Monocotyledoneae gen. et sp. indet. (Fig. 2C, D ) as well as roots indicate parautochthonous deposition for aquatic plants and such growing at the edge of the Steinheim lake.

Terrestrial plants mainly comprise leaves, leaf petioles, petioles and rhachis of compound leaves as well as different types of twigs. Due to the absence of winged fruits and flowering remains, except for ?Ailanthus sp. and Chaneya oeningensis (single specimens of both), we infer that wind transport played a minor role in the accumulation of plant debris and that terrestrial plant material probably stems from the vegetation in the lake's immediate surroundings. This interpretation is supported by the presence of parts of still compound leaves of Podocarpium podocarpum and of Sapindales fam., gen. et sp. 1 with leaflets still physically connected to the rhachis. Furthermore, we assume that most woody taxa in the closest lake surrounding were not anemochorous.

\section{Floristic composition}

The floristic spectrum of Steinheim (Tab. 1) is characterised by some remarkable pecularities that distinguish it from other plant assemblages: Not a single fern remain has been reported and this assemblage lacks any conifers. Daphnogene, which is probably the most common leaf type in fossil floras until the middle Miocene, is documented by a single, somewhat ambiguous leaf only (cf. Daphnogene polymorpha). Anemochorous taxa, i.e. with winged fruits, are largely absent except for Acer pseudomonspessulanum vel A. integrilobum, A. tricuspidatum vel A. angustilobum, ?Ailanthus sp., ?Carpinus sp., and Chaneya oeningensis, each documented by a single specimen only. Steinheim lacks further wind-dispersed taxa which are well known from many other sites similar in age, e.g. Betula, Ulmus, Tilia. Oaks are fairly diverse with 5 to 6 species (Q. drymeja, Q. ?gigas, Q. kubinyii, Q. mediterranea, Q. pseudocastanea, and maybe ?Quercus sp.). Among these, leaves of ?Quercus sp. are most abundant, while Q. ?gigas is represented by a single leaf fragment only. Remarkably, Steinheim yields at least three taxa with compound leaves: Podocarpium podocarpum, Sapindales fam., gen. et sp. 1 and 2 and possibly Ailanthus (?Ailanthus sp.). The findings of petioles and rhachis (?Sapindales fam., gen. et sp. - Petiole and rhachis of compound leaf) may derive from large compound leaves of possible Sapindales affinity. Celtis (C. japeti, C. lacunosa) and Podocarpium podocarpum are the only components that are documented both by leaves and fructifications.

This revision does not confirm, among others, the following taxa described by Gregor (1983) and/or Schweigert (1993) which would be ecologically and/ or climatically relevant: Isoëtes braunii - (recognised here instead as) indeterminable remain, Isoëtes sp. leaf rhachis and petiole of compound leaves, Persea princeps - Dicotylophyllum sp. 5, Smilax - Celtis japeti, Pistacia miochinensis - Sapindales fam., gen. et sp. 2, Zanthoxylum - ?Sapindales fam., gen. et sp. 1, Dikotylenrest (Phyllocladium) - fragment of a damaged leaf, Eichhornia - indeterminable remain.

The Steinheim assemblage yields both taxa characteristic in Central Europe during the late early and middle Miocene (P. podocarpium, Quercus drymeja, Q. mediterranea) as well as taxa characteristic of the late Miocene such as Quercus pseudocastanea and probably Quercus gigas (here Q. ?gigas) and Trapa (here ?Trapa sp.).

\section{Vegetation reconstruction (Tab. 2)}

The Steinheim taphocoenosis documents aquatic plants from the crater lake with both a submerged (Characeae, ?Potamogeton geniculatus,) and floating (Phyllites sp. ?floating leaf, ?Trapa sp.) lifestyle as well as reed and sedge-like plants from the edge of the lake (Cladiocarya trebovensis, Equisetum sp., possibly ?Lythraceae gen. et sp., Monocotyledoneae gen. et sp. indet., "Typha" oeningensis). 
Johanna Kovar-Eder \& Günter Schweigert • Revision of the plant assemblage of Steinheim am Albuch

Table 1. The revised floristic spectrum and the spectrum according to the treatment by Gregor (1983) and Schweigert (1993).

\begin{tabular}{|c|c|c|}
\hline This paper & Schweigert 1993 & Gregor 1983 \\
\hline Characeae & Characeae & Chara zolleriana \\
\hline Equisetum sp. & Phragmites oeningensis p.p. & \\
\hline cf. Daphnogene polymorpha & Daphnogene polymorpha & Dicotylophyllum sp. (Sapotaceae?) p.p. \\
\hline ?Potamogeton geniculatus & Potamogeton geniculatus & \\
\hline Cladiocarya trebovensis & Cladiocarya trebovensis & Cladiocarya trebovensis \\
\hline “Typha" latissima & Phragmites oeningensis p.p. & \\
\hline Monocotyledoneae gen et sp. indet. & $\begin{array}{l}\text { Phragmites oeningensis p.p., } \\
\text { Isoëtes braunii }\end{array}$ & \\
\hline Buxus pliocenica & Buxus cf. pliocenica p.p. & \\
\hline "Parrotia" pristina & Parrotia pristina & \\
\hline \multicolumn{3}{|l|}{ ?Trapa sp. } \\
\hline ?Lythraceae sp. & "Sapindus" falcifolius p.p. & \\
\hline Leguminosites $\mathrm{cf}$. hesperidum & Leguminocarpon sp. & \\
\hline Podocarpium podocarpum & Gleditsia knorrii & Gleditsia lyelliana, G. knorrii \\
\hline ?Carpinus sp. & Alnus gaudinii & \\
\hline Quercus drymeja & $\begin{array}{l}\text { Q. drymeja p.p., Zelkova zelkovaefolia p.p., } \\
\text { "Sapindus" falcifolius p.p. }\end{array}$ & \\
\hline Quercus gigas & Q. czeczottiae p.p. & \\
\hline Quercus kubinyii & $\begin{array}{l}\text { Quercus czeczottiae p.p., } \\
\text { Zelkova zelkovaefolia p.p. }\end{array}$ & Zelkova praelonga \\
\hline Quercus mediterranea & $\begin{array}{l}\text { Quercus mediterranea p.p., } \\
\text { Q. czeczottiae p.p. }\end{array}$ & Quercus spec. (Q. aff. mediterranea) \\
\hline Quercus pseudocastanea & Quercus pseudocastanea p.p. & \\
\hline ?Quercus sp. & Quercus drymeja p.p. & Tremophyllum tenerrimum \\
\hline Myrica sp. & Lonicera studeri p.p. & \\
\hline Populus balsamoides & Populus balsamoides & \\
\hline Celtis japeti & Celtis begonioides, Smilax weberi & cf. Byttneriophyllum tiliaefolium \\
\hline Celtis lacunosa & Celtis lacunosa & Celtis lacunosa \\
\hline Zelkova zelkovifolia & Zelkova zelkovaefolia p.p. & \\
\hline ?Rosaceae gen. et sp. indet. & Rosa lignitica & \\
\hline Acer monspessulanum vel $A$. integrilobum & Acer tricuspidatum p.p. & \\
\hline Acer tricuspidatum vel A. angustilobum & Acer tricuspidatum p.p. & \\
\hline Chaneya oeningensis & Astronium oeningense & \\
\hline ?Ailanthus sp. & Ailanthus confucii & \\
\hline Sapindales sp. 1 & Juglans acuminata p.p., Sapindus falcifolius p.p. & \\
\hline ?Sapindales sp. 1 & Zanthoxylum sp. & \\
\hline Sapindales sp. 2 & Pistacia miochinensis, Sapindus falcifolius p.p. & \\
\hline $\begin{array}{l}\text { ?Sapindales - petiole and rhachis } \\
\text { of compound leaves }\end{array}$ & Isoëtes sp. p.p. & \\
\hline Dicotylophyllum sp. 1 & Leguminosites sp. p.p. & Dicotylophyllum sp. (Sapotaceae ?) p.p. \\
\hline Dicotylophyllum sp. 2 & "Robinia" regelii & \\
\hline Dicotylophyllum sp. 3 & Populus mutabilis & \\
\hline Dicotylophyllum sp. 4 & Juglans acuminata p.p. & Persea princeps p.p. \\
\hline Dicotylophyllum sp. 5 & Lonicera studeri p.p. & \\
\hline Dicotylophyllum sp. 6 & Lonicera studeri p.p. & \\
\hline Dicotylophyllum sp. 7 & Dicotylophyllum (Phyllocladium) gen. et sp. indet. & \\
\hline \multicolumn{3}{|l|}{ Dicotylophyllum sp. 8} \\
\hline \multicolumn{3}{|l|}{ Phyllum sp. - ?floating leaf } \\
\hline \multicolumn{3}{|l|}{ Spiny branch } \\
\hline \multicolumn{3}{|l|}{ Twig with brachyblasts } \\
\hline \multicolumn{3}{|l|}{ Twig with buds or abcission marks } \\
\hline Plant remain indet. & Eichhornia sp. & \\
\hline
\end{tabular}


The terrestrial taxa represent the woody vegetation, forests and scrubs in the adjoining lake surroundings. Based on physiognomy and supposed autecology, Buxus pliocenica, Quercus drymeja, Q. kubinyii, Q. mediterranea, ?Quercus sp., and Dicotylophyllum sp. 3 may have grown preferably on south exposed slopes, on shallow, relatively dry soils or rocky underground prone to dryness. Celtis (C. japeti, C. lacunosa), Podocarpium podocarpum, Sapindales fam., gen. et sp. 2 and Zelkova zelkovifolia may also be grouped here.

Taxa with comparably large blades such as "Parrotia" pristina, Populus balsamoides, Quercus ?gigas, Q. pseudocastanea, Sapindales fam., gen. et sp. 1, and Dicotylophyllum sp. 4 may have preferred north exposure and more stable humid soil conditions. Contrary to floras from the early to early middle Miocene, the floristic record does not provide evidence that Lauraceae were essential components in these habitats. Acer pseudomonspessulanum vel A. integrilobum, Acer tricuspidatum vel A. angustifolia, ?Carpinus sp., Chaneya oeningensis, cf. Daphnogene polymorpha, Leguminosites cf. hesperidum, and Dicotylophyllum sp. div. - mostly documented by single specimens only - complement the composition of forests and scrubs covering the crater wall. Accordingly, the assumed communities may be characterised as subhumid sclerophyllous to broad-leaved deciduous forest types. This interpretation was tested by the application of the Integrated Plant Record (IPR)Vegetation Analysis (Kovar-Eder \& Kvaček 2007, KovarEder et al. 2008, refined by Teodoridis et al. 2011). This semiquantitative method was developed to assess overall zonal vegetation types. The results for Steinheim indicate subhumid sclerophyllous forests as most likely vegetation type and corroborate the empirical interpretation. The percentages of the main components are as follows: broad-leaved deciduous component $61 \%$, broad-leaved evergreen component $6 \%$, sclerophyllous + legume-like component 32\% (Appendix).

Schweigert's (1993) assumption of wet alluvial forests is problematic not only because proof of above-ground aquatic influx is not available but also due to the floristic composition, i.e. the diversity and abundance of oaks not characteristic of alluvial environments, the near absence of Betulaceae except for a single specimen (?Carpinus sp.), and the lack of Ulmus or Salix. As Schweigert (1993) recognised correctly, the flora of Steinheim lacks any indications of a (taxodioid) swamp environment near the lake.

Kirchner (1987) studied the pollen profile of a drilling from the Steinheim Basin. Although the composition did not undergo major changes along the profile, Kirchner distinguished three zones: Glyptostrobus dominance (34-20 m), Ulmus/Zelkova dominance (20-11 m), Abies dominance (11-6 m). The palynomorph record is poor in ferns but yields a diverse conifer and angisperm spectrum. Azonal taxa indicating wet environments are recorded, e.g. Taxodium/Glyptostrobus, Sequoia/Cryptomeria, Alnus, Populus, Salix, Ulmus as well as hinterland and higher altitude taxa, e.g. Abies, Picea. Among angiosperms, Juglandaceae (5), Ulmaceae (4), Betulaceae (3), Fagaceae (2), Salicaceae (2) are represented by more than one genus. The pollen record reflects a wider range of habitats than present in the macro record reflecting also farer distance influx. This divergence between pollen and macro record is not unusual. It was observed when the European pollen and macro record was studied to assess vegetation types (Kovar-Eder \& Kvaček 2007). Thus, the results from both sources are not in conflict, but rather are complementary to each other.

\section{Climate}

Based on isotopes $(\mathrm{C}, \mathrm{O}, \mathrm{Sr})$ of skeletal fossils of both aquatic and terrestrial animals, Tütken et al. (2006) derived a MAT of $18.8 \pm 3.8^{\circ} \mathrm{C}$ and a water temperature of the lake of 17 to $22^{\circ} \mathrm{C}$; they further conclude a warmtemperate and humid climate but "evaporation around the Steinheim Basin during the middle Miocene". The floristic composition of the Steinheim taphocoenosis points towards warm-temperate climatic conditions. The almost complete absence of Lauraceae and other laurophyllous foliage indicates cooler and/or drier conditions compared to previous periods. Quercus drymeja, Q. mediterranea, $? Q$. sp., and the small-sized foliage of Dicotylophyllum sp. 1 - all of which are documented not only by single specimens but by several to numerous remains - as well as the vegetation interpretation as subhumid sclerophyllous forest (based on the IPR-vegetation analysis) point to probably seasonal fluctuations in humidity, conforming with "evaporation around the Steinheim Basin" as expressed by Tütken et al. (2006). The presence of Buxus, Celtis, and Zelkova, which at least tolerate periodic drier climatic conditions today, further support this interpretation. In the diverse land snail fauna, Granaria is most abundant indicating warmer and drier conditions than in previous periods (Mammal Neogene Unit 5) (Höltke \& Rasser 2017). The landscape and climate reconstruction for the impact region and the impact period by Buchner \& Schmieder (2013) argues, however, for a subtropicalhumid climate. That interpretation, however, ignores completely not only the fossil plant record available from this region, but lacks differentiation of the hydrological regime of the relief and soils from climate and does not consider seasonal climatic fluctuations. Unfortunately, the poor preservation of the material hampers the application of CLAMP (Climate Leaf Analysis Multivariate Program) and the high taxonomical uncertainities hinder the 
Table 2. Floristic spectrum, abundance of taxa, inferred autecology, growth form, and fruit dispersal mode. Abundance classes: $1=1$ specimen, $2=2-5$ specimens, $3=6-10$ specimens, $4>10$ specimens.

\begin{tabular}{|c|c|c|c|c|}
\hline Taxon & abundance class & autecology & growth form & fruit dispersal mode \\
\hline Characeae & 1 & aquatic & herbaceous & \\
\hline Equisetum sp. & 3 & lake margin & herbaceous & \\
\hline cf. Daphnogene polymorpha & 1 & surrounding & woody & zoochorous-fleshy \\
\hline ?Potamogeton geniculatus & 4 & aquatic & herbaceous & hydro-/zoochorous-nonfleshy \\
\hline Cladiocarya trebovensis & 2 & lake margin & herbaceous & $?$ \\
\hline "Typha" latissima & 1 & lake margin & herbaceous & anemochorous \\
\hline Monocotyledoneae gen et sp. indet. & 4 & lake margin & herbaceous & anemochorous \\
\hline Buxus pliocenica & 1 & surrounding & woody & auto-/zoochorous-nonfleshy \\
\hline "Parrotia" pristina & 1 & surrounding & woody & anemo-/autochorous \\
\hline ?Trapa $\mathrm{sp}$ & 1 & aquatic & herbaceous & hydrochorous \\
\hline ?Lythraceae & 1 & lake margin & herbaceous/woody & $?$ \\
\hline Leguminosites cf. hesperidum & 1 & surrounding & woody & zoochorous-nonfleshy \\
\hline Podocarpium podocarpum & 4 & surrounding & woody & zoochorous-nonfleshy \\
\hline ?Carpinus sp. & 1 & surrounding & woody & anemochorous \\
\hline Quercus drymeja & 3 & surrounding & woody & zoochorous-nonfleshy \\
\hline Quercus ?gigas & 1 & surrounding & woody & zoochorous-nonfleshy \\
\hline Quercus kubinyii & 2 & surrounding & woody & zoochorous-nonfleshy \\
\hline Quercus mediterranea & 4 & surrounding & woody & zoochorous-nonfleshy \\
\hline Quercus pseudocastanea & 2 & surrounding & woody & zoochorous-nonfleshy \\
\hline ?Quercus sp. & 4 & surrounding & woody & ?zoochorous-nonfleshy \\
\hline Myrica sp. & 2 & surrounding & woody & zoochorous-fleshy \\
\hline Populus balsamoides & 2 & surrounding & woody & anemochorous \\
\hline Celtis japeti & 2 & surrounding & woody & zoochorous-fleshy \\
\hline Celtis lacunosa & 4 & surrounding & woody & zoochorous-fleshy \\
\hline Zelkova zelkovifolia & 3 & surrounding & woody & anemochorous \\
\hline ?Rosaceae gen. et sp. indet. & 1 & surrounding & woody & ?zoochorous-fleshy \\
\hline Acer pseudomonspessulanum vel A. integrilobum & 1 & surrounding & woody & anemochorous \\
\hline Acer tricuspidatum vel A. angustilobum & 1 & surrounding & woody & anemochorous \\
\hline Chaneya oeningensis & 1 & surrounding & woody & anemochorous \\
\hline ?Ailanthus sp. & 1 & surrounding & woody & ?anemochorous \\
\hline Sapindales sp. 1 & 4 & surrounding & woody & $?$ \\
\hline Sapindales sp. 2 & 3 & surrounding & woody & ? \\
\hline ?Sapindales - petiole and rhachis of compound leaf & 2 & surrounding & woody & $?$ \\
\hline Dicotylophyllum sp. 1 & 4 & surrounding & woody & $?$ \\
\hline Dicotylophyllum sp. 2 & 1 & surrounding & woody & $?$ \\
\hline Dicotylophyllum sp. 3 & 1 & surrounding & woody & ? \\
\hline Dicotylophyllum sp. 4 & 2 & surrounding & woody & ? \\
\hline Dicotylophyllum sp. 5 & 1 & surrounding & woody & $?$ \\
\hline Dicotylophyllum sp. 6 & 1 & surrounding & woody & $?$ \\
\hline Dicotylophyllum sp. 7 & 1 & surrounding & woody & $?$ \\
\hline Dicotylophyllum sp. 8 & 1 & surrounding & woody & $?$ \\
\hline Phyllum sp. - ?floating leaf & 1 & aquatic & herbaceous & $?$ \\
\hline Spiny branch & 2 & surrounding & woody & \\
\hline Twig with brachyblasts & 2 & surrounding & woody & \\
\hline Twig with buds or abcission marks & 2 & surrounding & woody & \\
\hline
\end{tabular}


application of the Coexistence Approach to assess further climatic signals.

\section{Comparison of the flora from Steinheim with relevant early/middle Miocene sites in Europe (Tab. 3)}

\section{Randeck Maar, Baden-Württemberg, Germany (late early/ early middle Miocene, MN 5)}

This sediment sequence of the Randeck Maar (RM) represents the filling of a maar lake, recently the subject of an ecosystem reconstruction (Rasser et al. 2013). The RM lake and the Steinheim impact crater lake were characterised by quiet sedimentation conditions mainly devoid of stream discharges. Both plant assemblages lack indications of a forested swamp environment in the lake surroundings.

Among aquatic plants, both sites share Characeae and possibly Potamogeton as well as monocotyledons as representatives of the lake margin. In RM, Sideroxylon salicites (Web.) Weyland, (Rüffle 1963) was recently recognised as Lythraceae foliage (Rasser et al. 2013) and ?Lythraceae gen. et sp. indicates the presence of the loosestrife family (except for ?Trapa sp.) also in Steinheim.

Among the terrestrial flora, both sites share the scarcity of both conifers and Betulaceae. The number of common taxa is rather limited, including Celtis, Populus balsamoides, Podocarpium podocarpum (abundant at both sites), Sapindales fam., gen. et sp. 2 (i.e. Sapindus falcifolius from RM), Zelkova zelkovifolia, and possibly Acer integrilobum. Both sites share the presence of further legumes [Leguminosites cf. hesperidum in Steinheim, Leguminocarpon bousqueti (Sap.) Rüffle in RM]. Sapindales taxa with compound leaves do occur in both assemblages though partly with different taxa, e.g. Koelreuteria (Simaroubaceophyllum picrasmoides Rüffle only at RM). Contrary to Steinheim, the Fagaceae record from RM is rather poor, in which Castanea atavia Ung. may represent an oak similar to $Q$. drymeja or Q. kubinyii from Steinheim. Also in contrast with Steinheim, Lauraceae are well represented at RM.

While winged fruits are almost absent at Steinheim, such fruits are diverse at RM, representing Acer, Ailanthus, Cedrelospermum, Craigia, Engelhardia, Hydrangea, Saportaspermum, and Ulmus.

For RM, the assumed habitat reconstruction postulates subhumid sclerophyllous and mixed-mesophytic forests on the crater slopes and adjacent hinterland depending on soil conditions and sun exposure (Rasser et al. 2013). This differentiation is partly in agreement with Steinheim, where we assume subhumid sclerophyllous forests.
Engelswies, southern Baden-Württemberg, Germany (late early/early middle Miocene, MN 5)

The plant assemblage from Engelswies (Schweigert 1992) developed under a very different ecological setting. Terrestrial plants include Glyptostrobus, Magnolia, Liquidambar, Daphnogene, Acer tricuspidatum (non Symplocos cf. hallensis Barthel, Kvaček \& Rüffle in Schweigert 1992), and a fan palm. Except for Daphnogene and Acer (single remains only) these taxa do not occur at Steinheim. Vice versa, Engelswies lacks any oaks and Podocarpium podocarpum, which are common at Steinheim. Any further comparison would have little scientific basis because the flora from Engelswies deserves revision as well.

Schrotzburg, southwestern Baden-Württemberg, Germany (late middle Miocene)

The Schrotzburg plant assemblage (Hantke 1954) belongs to the Öningen complex, which is of fluvial lacustric origin. The taxa characteristic of riparian environments such as Daphnogene, Platanus, Liquidambar, Ulmus, Acer angustilobum, Populus balsamoides, and Salix are most common, thus distinguishing this flora from Steinheim. The following similarities to Steinheim may be recognised: the absence of conifers except for few findings of Glyptostrobus and the presence of Podocarpium podocarpum and Quercus mediterranea.

Cypris Shale, Western Bohemia, Czech Republic (early Miocene)

The Cypris Shale flora (Bůžek et al. 1996) is dated to MN 4b and 5 based on mammals in the Cheb Basin. It yields taxa that are characteristic of the Early Miocene such as Platanus neptuni (Ettingsh.) Bůžek, Holý \& Kvaček, Trigonobalanopsis and several Lauraceae but lacks taxa characteristic to later periods such as Quercus pseudocastanea. The floristic spectrum is rich both in conifers and angiosperms covering different habitats from aquatic facies, lignite swamps, riparian settings to wider upland habitats. Remarkable shared taxa of both sites are Quercus kubinyii, Podocarpium podocarpum, Zelkova zelkovifolia, possibly Acer pseudomonspessulanum and Celtis lacunosa and, on the generic level, Buxus and possibly Ailanthus.

Parschlug, Styria, Austria (late early/early middle Miocene)

Based on mammals and the floristic composition, Parschlug is assigned to the Karpatian/early Badenian (Central Paratethys stages) (Kovar-Eder et al. 2004). The assemblage is a mixture in which a limited number 
of taxa characteristic of lignite swamps is dominant [mainly Glyptostrobus europaeus (Brongniart) Unger, Liquidambar europaea A. Braun, Myrica lignitum (Unger) Saporta], while numerous taxa, probably representing the hinterland flora, are far less common or even documented by few or single specimens only. Generally, the flora of Parschlug is far more diverse than the assemblage from Steinheim. Parschlug and Steinheim share Celtis japeti, Podocarpium podocarpum, Zelkova zelkovifolia, and possibly also Acer monspessulanum, Chaneya and Leguminosites hesperidum. Oaks are more diverse in Steinheim than in Parschlug (Steinheim 5-6 species, Parschlug 4) but represented by different species except for $Q$. drymeja and $Q$. mediterranea. Both sites share also Buxus but with differences at the species level (B. cf. egeriana Kvaček, Bůžek \& Holý in Parschlug). Based on the number of small-sized, probably evergreen sclerophyllous taxa, a less humid climate than in earlier and later periods, with seasonal changes in precipitation, was assumed for Parschlug (Kovar-Eder et al. 2004); this conforms with the Steinheim record.

\section{Türkenschanze, Vienna Basin, Austria (late middle Miocene, Sarmatian)}

This plant assemblage derives from marine to brackish sediments at the northwestern margin of the Pannonian Lake, the Vienna Basin (Berger \& Zabusch 1953). It represents the vegetation along streams as well as from the nearby hinterland and is characterised by a stronger allochthonous influence than the Steinheim assemblage. Both sites share the presence of Buxus pliocenica, Quercus mediterranea, Zelkova zelkovifolia, and probably Acer integrilobum, Podocarpium podocarpum, $Q$. drymeja, and Myrica. Daphnogene polymorpha [there as Cinnamomum scheuchzeri (Heer) Kräusel \& Weyland] is rare at Türkenschanze as is cf. Daphnogene polymorpha at Steinheim. Populus is represented by $P$. populina (formerly $P$. latior A. Braun) at Türkenschanze while by $P$. balsamoides at Steinheim. Numerous taxa are small-leaved and taxonomic assignment is difficult at Türkenschanze. Among these, "Persoonia" tusca Gaudin (Berger \& Zabusch 1953) reminds of Dicotylophyllum sp. 1 from Steinheim. Contrary to Steinheim, pine needles are quite common at Türkenschanze. Among others, this assemblage differs further by the presence of Crataegus, Ulmus, and possibly of Juglans. Based on the overall character and numerous relatively small-sized leaf taxa Berger \& Zabusch (1953) assumed rather dry climatic conditions. Their vegetation interpretation "Macchia and Hartlaubgehölze" and "Savanna und Buschsteppe" has not been confirmed by any further palaeobotanical study in this part of Europe. It is by far exagerated. A sclerophyllous impact in mesophytic hinterland forests due to drier climatic conditions may, however, be assumed for Türkenschanze and Berger \& Zabusch (1953) recognised a relationship to the flora of Erdőbenye (Hungary).

Erdöbenye, Tallya, Hungary (middle Miocene, middle Serravalian)

The flora from Erdőbénye (Kováts 1856, Andreánszky 1959 ) is early Sarmatian in age (Central Paratethys stage) and stems from marine deposits. Thus, both sites underwent very different taphonomical processes: the Erdőbénye plant assemblage has a much stronger allochthonous impact than the Steinheim taphocoenosis. This at least partly accounts for the higher diversity at Erdőbénye than at Steinheim. Although this flora deserves revision, and therefore the comparison is limited, it is evident that Steinheim and Erdőbénye share oaks indicating different ecological requirements: $Q$. kubinyii, $Q$. mediterranea, $Q$. pseudocastanea, but oak diversity is lower in Erdöbénye than in Steinheim. Both sites further share Celtis japeti (formerly C. trachytica Ettingsh., see Kovar-Eder et al. 2004), Zelkova zelkovifolia and possibly Acer integrilobum (Acer inaequilobum Kováts partim, see synonymy Ströbitzer-Hermann 2002). Sapindus erdöbenyensis Kováts is reminiscent of Sapindales fam., gen. et sp. 2. Otherwise, Erdőbénye differs among others by the presence of conifers (both Pinaceae and Taxodioideae) as well as the occurrence of Fagus, Carpinus, Ulmus, and Juglandaceae to mention a few.

\section{Kymi, Evia Island, Greece (early Miocene, Aquitanian)}

A rough revision of this famous flora, which was studied monographically by Unger (1867), has been presented by Velitzelos, E. et al. (2002). The assemblage of Kymi is more diverse than Steinheim, including both evergreen and deciduous taxa from different settings such as swamp facies (Glyptostrobus europaeus and Myrica div. sp.) and hinterland forests. Remarkably, Kymi and Steinheim share Q. drymeja and Q. mediterranea as well as Zelkova zelkovifolia. Lauraceae at Kymi are documented by three species at least including Daphnogene polymorpha, which is the only one that may be present at Steinheim. Kymi differs from Steinheim by the occurrence of several species of Betulaceae, Fagus and Trigonobalanopsis (Fagaceae), and Engelhardia, to mention some. Vice versa, Kymi lacks roburoid oaks. Differences in taphonomical settings, geographic position as well as in age account for the differences.

\section{Vegora, Macedonia, Greece (late Miocene)}

The flora of Vegora (Kvaček et al. 2002) derives from marles superimposed on lignites. These sediments were 


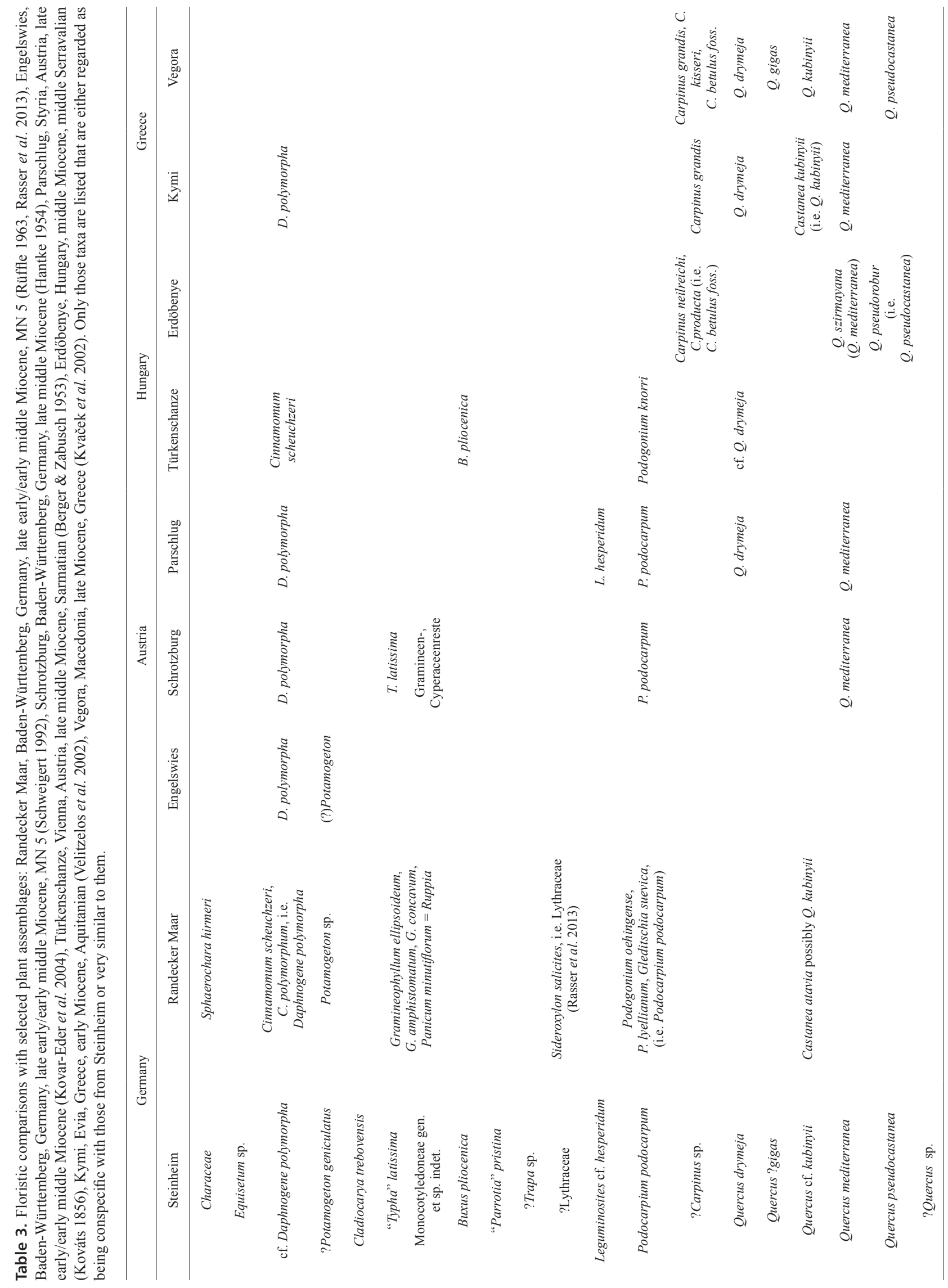




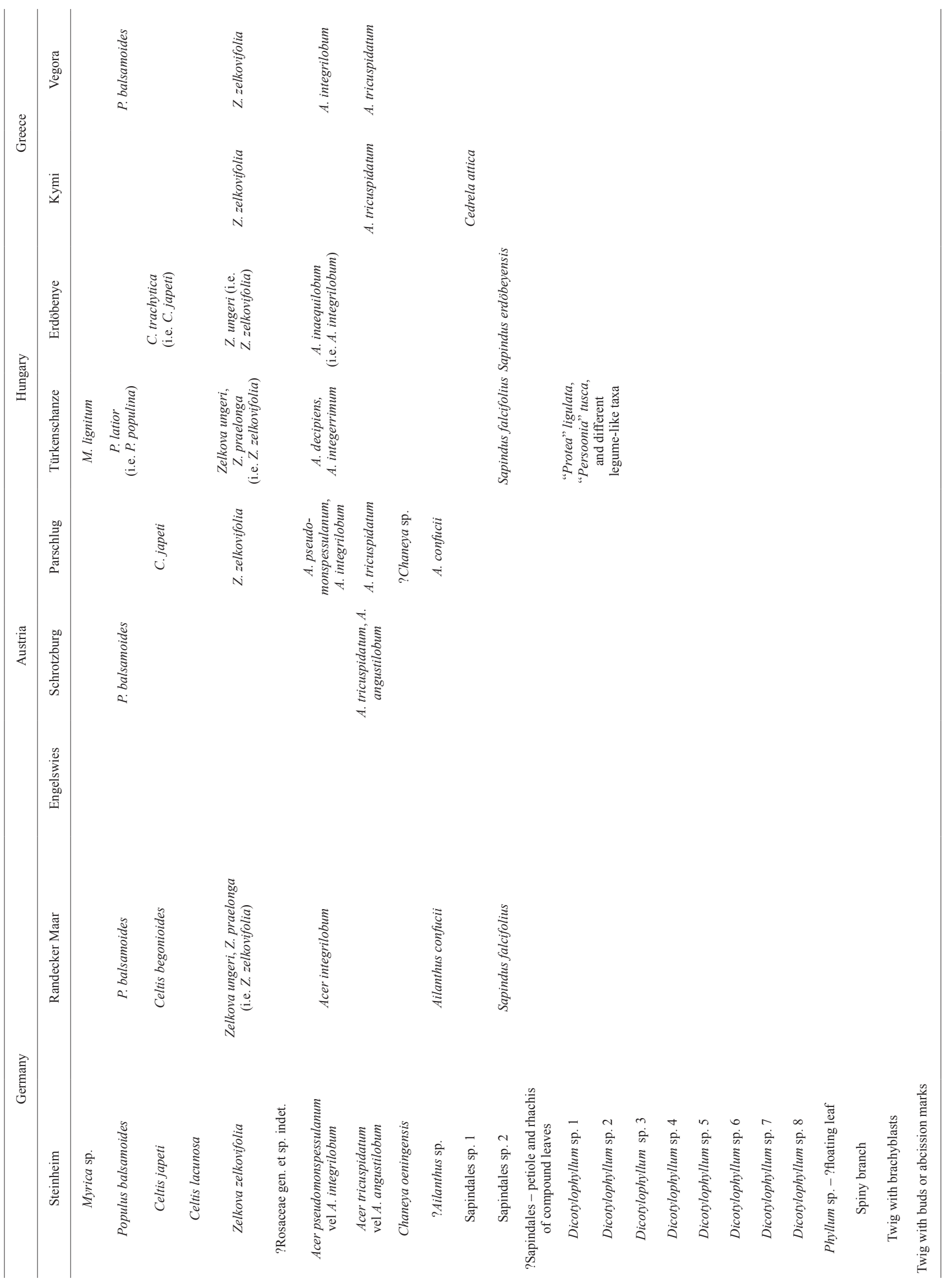


dated based on mammals to the Ruscinian. The plant assemblage is characterised by a mixture of woody taxa from azonal settings (swampy to riparian) and zonal environments (hinterland forests). Thus, it is rather diverse. Steinheim and Vegora share the diversity of oaks, which is even higher in Vegora including $Q$. sosnowskyi Kolakovskii, in addition to the oak species present at Steinheim. In Vegora, Q. mediterranea and sosnowskyii, which likely were evergreen, are interpreted as part of sclerophyllous scrub-like woodland along with Cupressaceae and pines. In Steinheim, none of these Q. mediterranea-accompanying taxa have been discovered. Vegora differs further by the diversity of conifers (both Taxodioideae and Pinaceae), Betulaceae (Alnus, Betula, Carpinus), and maples, as well as by the presence of Ginkgo, Fraxinus, Lauraceae (Sassafras, Daphnogene, Laurophyllum), Pterocarya, Ulmus, among others.

\section{Acknowledgements}

This study was initiated and strongly encouraged by M. Rasser (Stuttgart). H.-J. Gregor (Olching), L. Hably (Budapest), Z. Kvaček (Prague), S. Manchester (Gainsville), and M. Thiv (Stuttgart) supported this revision with scientific discussions. H. Sommer prepared the plates in the usual professional manner. We are very grateful to all for their support. Finally we would like to thank the reviewers for their useful comments to improve our manuscript.

\section{References}

Adam, K.D. 1980. Das Steinheimer Becken - eine Fundstätte von Weltgeltung. Jahreshefte der Gesellschaft für Naturkunde in Württemberg 135, 31-144.

Aiglstorfer, M., Costeur, L., Mennecart, B. \& Heizmann, E.P.J. 2017. Micromeryx? eiselei - A new moschid species from Steinheim am Albuch, Germany, and the first comprehensive description of moschid cranial material from the Miocene of Central Europe. PLoS ONE 12(10), e0185679.

DOI 10.1371/journal.pone.0185679

Andreánszky, G. 1959. Die Flora der sarmatischen Stufe in Ungarn. 360 pp. Akadémiai Kiado, Budapest.

BAJOR, M. 1965. Zur Geochemie der tertiären Süßwasserablagerungen des Steinheimer Beckens, Steinheim am Albuch (Württemberg). Jahreshefte des geologischen Landesamtes Baden-Württemberg 7, 355-386.

Berger, W. \& Zabusch, F. 1953. Die obermiozäne (sarmatische) Flora der Türkenschanze in Wien. Neues Jahrbuch für Geologie und Paläontologie Abhandlungen 98(2), 226-276.

Braun, A. 1845. Die Tertiär-Flora von Öningen. Neues Jahrbuch für Mineralogie, Geologie, Geognosie und PetrefactenKunde 1845, 164-173.

Buchner, E. \& Schmieder, M. 2013. Das Ries-Steinheim-
Ereignis - Impakt in eine miozäne Seen- und Sumpflandschaft. Zeitschrift der Deutschen Gesellschaft für Geowissenschaften 164, 459-470. DOI 10.1127/1860-1804/2013/0020

Buchner, E. \& Schmieder, M. 2017. Rare metals on shatter cone surfaces from the Steinheim Basin (SW Germany) - remnants of the impacting body? Geological Magazine, 1-25.

DOI 10.1017/S0016756816001357

Buchner, E., Hölzel, M., Schmieder, M., Rasser, M., Fietzke, J., Frische, M. \& Kutterolf, S. 2017. A meteorite fragment trapped between positive and negative shatter cones in a limestone block stored at the Meteorkrater-Museum Steinheim, Germany. Meteoritics and Planetary Science, Special Issue: $80^{\text {th }}$ Annual Meeting of the Meteoritical Society, Santa Fe, New Mexico, USA (23 $3^{\text {rd }}-28^{\text {th }}$ July 2017), Volume 52, Issue Supplement S1, 6014.

Buchner, E., Schmieder, M., Schwarz, W.H. \& Trieloff, M. 2013. Das Alter des Meteoritenkraters Nördlinger Ries - eine Übersicht und kurze Diskussion der neueren Datierungen des Riesimpakts. Zeitschrift der Deutschen Gesellschaft für Geowissenschaften 164, 433-445. DOI 10.1127/1860-1804/2013/0037

BưžEK, C., HolÝ, F. \& KvačEK, Z, 1996. Early Miocene flora of the Cypris Shale (Western Bohemia). Acta Musei Nationalis Pragae, Serie B, Historia Naturalis 52, 1-72.

Corbett, S.L. \& Manchester, S.E. 2004. Phytogeography and fossil history of Ailanthus (Simaroubaceae). International Journal of Plant Sciences 165, 671-690. DOI 10.1086/386378

Czeczott, H. 1951. The Middle Miocene flora of Zaleśce near Wiśniowiec (Wolhynia) I. Acta Geologica Polonica 2, 349-445.

Ellis, B., Daly, D.C., Hickey, L.J., Johnson, K.R., Mitchell, J.D., Wilf, P. \& Wing, S.L. 2009. Manual of Leaf Architecture. 200 pp. Cornell University Press, Ithaca.

Ettingshausen, C. von 1851. Die Tertiaer-Floren der Oesterreichischen Monarchie. 1. Fossile Flora vom Wien. Abhandlungen der Geologischen Reichsanstalt 2, 1-36.

Ettingshausen, C. von 1853. Beitrag zur Kenntniss der fossilen Flora von Tokay. Sitzungsberichte der Kaiserlichen Akademie der Wissenschaften, mathematisch-naturwissenschaftliche Classe 9, 779-816.

FINGER, I. 1998. Gastropoden der kleini-Schichten des Steinheimer Beckens (Miozän, Süddeutschland). Stuttgarter Beiträge zur Naturkunde, Serie B 259, 1-51.

Gaudant, J. 1989. Nouvelles observations sur l'ichthyofaune miocène de Steinheim am Albuch (Wurttemberg, Allemagne). Stuttgarter Beiträge zur Naturkunde, Serie B 151, 1-33.

Göppert, H.R. 1852. Beiträge zur Tertiärflora Schlesiens. Palaeontographica 2, 257-282.

Göppert, H.R. 1855. Die tertiäre Flora von Schossnitz in Schlesien. 52 pp. Heyn'sche Buchhandlung, Görlitz.

Gorthner, A. 1992. Bau, Funktion und Evolution komplexer Gastropodenschalen in Langzeit-Seen. Stuttgarter Beiträge zur Naturkunde, Serie B 190, 1-173.

Gregor, H.-J. 1983. Die miozäne Blatt- und Frucht-Flora von Steinheim am Albuch (Schwäbische Alb). Documenta naturae 10, 1-45.

Gregor, H.-J. \& HantKe, R. 1980. Revision der fossilen 
Leguminosengattung Podogonium Heer (= Gleditsia Linné) im europäischen Jungtertiär. Feddes Repert 91, 151-182. DOI 10.1002/fedr.19800910303

Hably, L. 1992. Distribution of legumes in the Tertiary of Hungary, 169-187. In Herendeen, P.S. \& Dilcher, D.L. (eds) Advances in Legume Systematics: Part 4. The Fossil Record.

Hably, L. \& Thí́BAut, M. 2002. Revision of Cedrelospermum (Ulmaceae) fruits and leaves from the Tertiary of Hungary and France. Palaeontographica Abteilung B 262, 71-90.

HantKe, R. 1954. Die fossile Flora der obermiozänen OehningerFundstelle Schrotzburg (Schienerberg, Süd-Baden). Denkschriften der Schweizerischen Naturforschenden Gesellschaft 80/2, 1-118.

HeEr, O. 1855. Flora tertiaria Helvetiae I. 118 pp. J. Wurster \& Company, Winterthur.

HeEr, O. 1856. Flora tertiaria Helvetiae II. 110 pp. J. Wurster \& Company, Winterthur.

HeER, O. 1859. Flora tertiaria Helvetiae III. 378 pp. J. Wurster \& Company, Winterthur.

Heizmann, E.P.J. 1992. Das Tertiär in Südwestdeutschland. Stuttgarter Beiträge zur Naturkunde, Serie C 33, 1-61.

Heizmann, E.P.J. \& Hesse, A. 1995. Die mittelmiozänen Vogelund Säugetierfaunen des Nördlinger Ries (MN6) und des Steinheimer Beckens (MN7) - ein Vergleich. Courier Forschungsinstitut Senckenberg 181, 171-185.

Heizmann, E.P.J. \& Reiff, W. 2002. Der Steinheimer Meteorkrater. 160 pp. Verlag Dr. Friedrich Pfeil, München.

Heizmann, E.P.J., Duranthon, F. \& Tassy, P. 1996. Miozäne Großsäugetiere. Stuttgarter Beiträge zur Naturkunde, Serie C 39, 1-60.

Herendeen, P.S. 1992a. Podocarpium podocarpum comb. nov. correct name for Podogonium knorrii Heer, nom. illeg. (fossil Fabaceae). Taxon 41, 731-736. DOI 10.2307/1222400

HerendeEn, P.S. 1992b. A re-evaluation of the fossil genus Podogonium Heer, 3-18. In Herendeen, P.S. \& Dilcher, D.L. (eds) Advances in legume systematics, part 4, the fossil record.

Heywood, V.H., Brummitt, R.K., Culham, A. \& Seberg, O. 2007. Flowering plant families of the world. 424 pp. Royal Botanical Garden Kew, London.

Hilgendorf, F. 1867. Über Planorbis multiformis im Steinheimer Süßwasserkalk. Monatsberichte der Königlich Preussischen Akademie der Wissenschaften zu Berlin 1866, 474-504.

Höltke, O. \& Rasser, M.W. 2015. Pseudochloritis insignis A peculiar large land-snail from the Miocene of SW Germany: Taxonomic status and census of morphologically related forms. Journal of Conchology 42(1), 1-12.

Höltke, O. \& Rasser, M.W. 2017. Land snails from the Miocene Steinheim impact crater lake sediments (BadenWürttemberg, South Germany). Neues Jahrbuch für Geologie und Paläontologie Abhandlungen 285(3), 267-302.

DOI 10.1127/njgpa/2017/0681

Iljinskaja, I.A. 1994. In Budantsev, L. (ed.) Magnoliophyta Fossilia Rossiae et Civitatum Finitimarum. Vol. 3. 118 pp. Institutum Botanicum Komarovianum Academiae Scientiarum Rossicum, St. Petersburg. [in Russian]

JANZ, H. 1992. Die miozänen Süßwasserostrakoden des
Steinheimer Beckens (Schwäbische Alb, Süddeutschland). Stuttgarter Beiträge zur Naturkunde, Serie B 183, 1-117.

JANZ, H. 1997. Die Ostrakoden der kleini-Schichten des miozänen Kratersees von Steinheim am Albuch (Süddeutschland). Stuttgarter Beiträge zur Naturkunde, Serie B 251, $1-101$.

Kirchner, M. 1987. Ein kurzer Abriß der Mikroflora von Steinheim am Albuch. Mitteilungen der Bayerischen Staatssammlung für Paläontologie und historische Geologie 27, 105-121.

KNobloch, E. \& KvačeK, Z. 1976. Miozäne Blätterfloren vom Westrand der Böhmischen Masse. Rozpravy Ústředního ústavu geologického 42, 5-129.

Kotlaba, F. 1963. Tertiary plants from three new localities in southern Slovakia. Sbornik Národního muzea v Praze, Řada $B$, Prírodni védy 19, 53-74.

KovÁcs, E. 1957. Comparative studies on the Sarmatian flora and ecology of Bánhorváti and other localities. Földtani Közlöny 87, 425-446.

Kovar-Eder, J. \& KVAČEK, Z. 2007. The integrated plant record (IPR) to reconstruct Neogene vegetation - the IPR vegetation analysis. Acta Palaeoboanica 47(2), 391-418.

Kovar-Eder, J. Kvaček, Z. \& Ströbitzer-Hermann, M. 2004. The Miocene Flora of Parschlug (Styria, Austria) - Revision and Synthesis. Annalen des Naturhistorischen Museums Wien $105 \mathrm{~A}, 45-159$.

Kovar-Eder, J., Schwarz, J. \& Wójcicki, J.J. 2002. The predominantly aquatic flora from Pellendorf, Lower Austria, Late Miocene, Pannonian - a systematic study. Acta Palaeobotanica 42, 125-151.

Kovar-Eder, J., Jechorek, H., Kvaček, Z. \& Parashiv, V. 2008. The integrated plant record: the ultimate tool to reconstruct Neogene zonal vegetation in Europe. Palaios 23, 97-111. DOI 10.2110/palo.2006.p06-039r

Kováts, J. 1856. Fossile Flora von Erdöbenye. Arbeiten der geologischen Gesellschaft für Ungarn 1, 1-37.

Kunzmann, L. \& Walther, H. 2007. A noteworthy plant taphocoenosis from the Lower Oligocene Haselbach Member (Saxony, Germany) containing Apocynophyllum neriifolium Heer. Acta Palaeobotanica 47, 145-161.

KVAČEK, Z. 1995a. Limnobiophyllum Krassilov - a fossil link between the Araceae and Lemnaceae. Aquatic Botany 50, 49-61. DOI 10.1016/0304-3770(94)00442-O

KVAČEK, Z. 1995b. The Hydrocharitaceae foliage from the North Bohemian Early Miocene. Věstník Českého geologického ústavu 70(2), 21-28.

KVAČEK, Z. \& SAKALA, J. 1999. Twig with attached leaves, fruits and seeds of Decodon (Lythraceae) from the Lower Miocene of northern Bohemia, and implications for the identification of detached leaves and seeds. Review of Palaeobotany and Palynology 107, 201-222.

DOI 10.1016/S0034-6667(99)00022-6

KVAČEK, Z. \& WALther, H. 1998. The Oligocene flora of Kundratice near Litoměřice, České Středohoří volcanic complex (Czech Republic) - a review. Sborník Národního muzea v Praze, ̌̌ada B, Prírodní védy 54(1-2), 1-42.

Kvaček, Z., Velitzelos, D. \& Velitzelos, E. 2002. Late Miocene 
flora of Vegora, Macedonia, N Greece. 175 pp. University of Athens, Athens.

MAnCHester, S.R. 1989. Attached reproductive and vegetative remains of the extinct American-European genus Cedrelospermum (Ulmaceae) from the early Tertiary of Utah and Colorado. American Journal of Botany 76, 256-276. DOI 10.1002/j.1537-2197.1989.tb11309.x

Manchester, S.R. \& Zastawniak, E. 2007. Fruit with perianth remains of Chaneya Wang \& Manchester (extinct Rutaceae) in the Upper Miocene of Sośnica, Poland. Acta Palaeobotanica 47, 253-259.

MeIn, P. 1975. Résultats du Groupe de Travail des Vertébrés, 78-81. In SENES, J. (ed.) Report on activity RCMNS-Working groups (1971-1975). SAV, Bratislava.

Mein, P. 1989. Updating of MN zones, 73-90. In Lindsay, E.H., Fahlbusch, V. \& Mein, P. (eds) European Neogene Mammal Chronology. Plenum, New York.

Menitsky, Yu. 1984: Duby Asii. 316 pp. Akademiya Nauk SSSR, Leningrad. [in Russian]

Mensink, H. 1984. Die Entwicklung der Gastropoden im miozänen See des Steinheimer Beckens (Süddeutschland). Palaeontographica, Abteilung A 183, 1-63.

Nützel, A. \& BAndel, K. 1993. Studies on the sidebranch planorbids (Mollusca, Gastropoda) of the Miocene crater lake of Steinheim am Albuch (southern Germany). Scripta Geologica Special Issue 2, 313-357.

Povel, G.D.E. 1993. The main branch of Miocene Gyraulus (Gastropoda; Planorbidae) of Steinheim (southern Germany): a reconsideration of Mensink's data set. Scripta Geologica Special Issue 2, 371-386.

RASSER, M.W. 2006. 140 Jahre Steinheimer SchneckenStammbaum: der älteste fossile Stammbaum aus heutiger Sicht. Geologica et Palaeontologica 40, 195-199.

Rasser, M.W. 2013a. Evolution in Isolation: The Gyraulus species flock from Miocene Lake Steinheim revisited. Hydrobiologia 739, 7-24.

DOI 10.1007/s10750-013-1677-4

Rasser, M.W. 2013b. Darwin's dilemma: The Steinheim snails' point of view. Zoosystematics and Evolution 89, 13-20. DOI 10.1002/zoos.201300002

Rasser, M.W. \& Covich, A.P. 2014. Predation on freshwater snails in Miocene Lake Steinheim: a trigger for intralacustrine evolution? Lethaia 47, 524-532. DOI 10.1111/let.12078

Rasser, M.W., Bechly, G., Böttcher, R., Ebner, M., Grein, M., Harzhauser M., Heizmann, E.P.J., Höltke, O., Joachim, C., Kern, A.K., Kovar-Eder, J., Nebelsick, J.H., RothNebelsick, A., Schoch, R., Schweigert, G. \& Ziegler, R. 2013. The Miocene Randeck Maar revisited: Life in and around a peculiar volcanogenic lake. Palaeogeography, Palaeoclimatology, Palaeoecology 392, 426-453.

DOI 10.1016/j.palaeo.2013.09.025

REIF, W.-E. 1983. The Steinheim snails (Miocene; Schwäbische Alb) from a Neo-Darwinian point of view: a discussion. Paläontologische Zeitschrift 57, 21-26.

DOI 10.1007/BF03031746

ReIFF, W. 1988. Zur Gleichaltrigkeit der Einschlagkrater (Meteorkrater) des Steinheimer Becken und Nördlinger
Ries. Jahresberichte und Mitteilungen des oberrheinischen geologischen Vereins, Neue Folge 70, 383-397.

REIFF, W. 1992. Zur Entwicklung des Steinheimer Beckens. Jahreshefte des geologischen Landesamtes BadenWürttemberg 34, 305-318.

REIFF, W. 2004. Erläuterungen zur Geologischen Karte von Baden-Württemberg 1:25.000, Blatt 7326 Heidenheim. Freiburg im Breisgau (Landesamt für Geologie, Rohstoffe und Bergbau Baden-Württemberg). VII + 223 pp. LGBR, Freiburg.

RÜFFLE, L. 1963. Die obermiozäne (sarmatische) Flora vom Randecker Maar. Paläontologische Abhandlungen 1(3), 139-298.

Saporta, G. DE \& Marion, A.F. 1876. Recherches sur les végétaux fossiles de Meximieux. Arches du Muséum d'histoire naturelle Lyon 1, 131-335.

Schweigert, G. 1992. Die untermiozäne Flora (Karpatium, MN 5) des Süßwasserkalks von Engelswies bei Messkirch (Baden-Württemberg). Stuttgarter Beiträge zur Naturkunde, Serie B 188, 1-55.

Schweigert, G. 1993. Die mittelmiozäne Fora (MN 7) von Steinheim am Albuch (Schwäbische Alb, BadenWürttemberg). Jahreshefte der Gesellschaft für Naturkunde 148, 61-96.

STEInINGER, F.F. 1999. Chronostratigraphy, geochronology and biochronology of the Miocene "European Land Mammal Mega-Zones (ELMMZ)" and the Miocene "Mammal-Zones (MN-Zones)", 9-24. In Rössner, G.E \& Heissig, K. (eds) The Miocene Land Mammals of Europe. Verlag Dr. Friedrich Pfeil, München.

Stitzenberger, E. 1851. Übersicht der Versteinerungen des Großherzogthums Baden. 144 pp. Diernfellner, Freiburg.

Ströbitzer-Hermann, M. 2002. Systematik, Variabilität, regionale und stratigraphische Verbreitung sowie Ökologie der Gattung Acer L. in Mitteleuropa vom Oligo- bis ins Pliozän. 149 pp. Ph.D. thesis, Universität Wien, Wien, Austria.

Stur, D. 1867. Beiträge zur Kenntnis der Flora der Süßwasserquarze, der Congerien- und der Cerithienschichten im Wiener und Ungarischen Becken. Jahrbuch der kaiserlichköniglichen Geologischen Reichsanstalt 17, 77-188.

TeOdoridis, V. \& KVAČEK, Z. 2005. The extinct genus Chaneya Wang et Manchester in the Tertiary of Europe - a revision of Porana-like fruit remains from Öhningen and Bohemia. Review of Palaeobotany 134, 85-103.

DOI 10.1016/j.revpalbo.2004.12.002

Teodoridis, V., Kovar-Eder, J. \& Mazouch, P. 2011. Integrated plant record (IPR) vegetation analysis applied to modern vegetation in southeastern China and Japan. Palaios 26, 623-638. DOI 10.2110/palo.2010.p10-149r

Tütken, T., Vennemann, T.W., Janz, H. \& Heizmann, E.P.J. 2006. Palaeoenvironment and palaeoclimate of the Middle Miocene lake in the Steinheim basin, SW Germany: A reconstruction from $\mathrm{C}, \mathrm{O}$, and $\mathrm{Sr}$ isotopes of fossil remains. Palaeogeography, Palaeoclimatology, Palaeoecology 241, 457-491. DOI 10.1016/j.palaeo.2006.04.007

UnGER, F. 1841-1847. Chloris protogaea. Beiträge zur Vorwelt. CX, 150 pp. W. Engelmann, Leipzig. 
Unger, F. 1850. Genera et species plantarum fossilium. 628 pp. W. Braumüller, Wien.

UnGer, F. 1852. Iconographia plantarum fossilium. Denkschriften der kaiserlichen Akademie der Wissenschaften, mathematisch-naturwissenschaftliche Classe 4, 73-118.

UnGER, F. 1867. Die fossile Flora von Kumi auf der Insel Euboea. Denkschriften der Kaiserlichen Akademie der Wissenschaften, mathematisch-naturwissenschaftliche Classe 27, 27-87.

Velitzelos, E., Kvaček, Z., Denk, T. \& Velitzelos, D. 2002. Palaeontology and Palaeobotany, 1-61. In Velitzelos, D. (ed.) Field guide to the Neogene of the Island of Evia Early Miocene flora of Kymi. $6^{\text {th }}$ European PalaeobotanyPalynology Conference.
Walther, H. 1999. Die Tertiärflora von Kleinsaubernitz bei Bautzen. Palaeontographica Abteilung B 249, 63-174.

Walther, H. \& KvačeK, Z. 2007. Early Oligocene flora of Seifhennersdorf (Saxony). Sbornik Národniho muzea v Praze, Řada B, Prírodní védy 63(2-4), 85-164.

WAnG, Y. \& Manchester, S.R. 2000. Chaneya, a new genus of winged fruits from the Tertiary of North America and Eastern Asia. International Journal of Plant Science 161, 167-178. DOI 10.1086/314227

Wolff, M. \& Füchtbauer, H. 1976. Die karbonatische Randfazies der tertiären Süßwasserseen des Nördlinger Ries und des Steinheimer Beckens. Geologisches Jahrbuch, Reihe D 14, 3-53. 
Appendix. Score list for the Integrated Plant Record (IPR) Vegetation Analysis according to (Teodoridis et al. 2011).

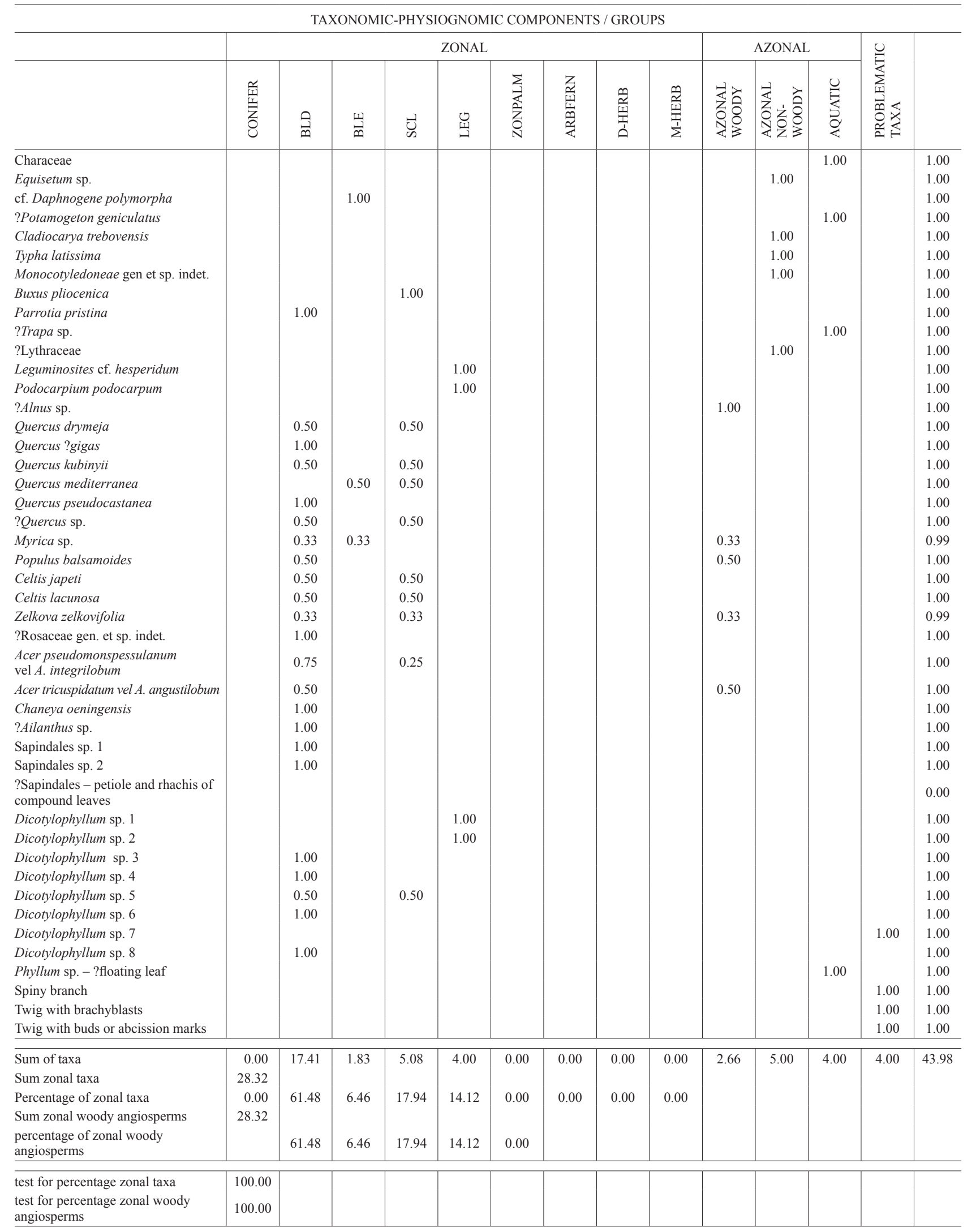

Result; BLD 61\%, BLE 6\%, SCL + LEG 32\% $\rightarrow$ subhumid sclerophyllous forest 